\title{
Repurposing the quinoline antibiotic nitroxoline to treat infections caused by the brain-eating amoeba Balamuthia mandrillaris
}

Matthew T. Laurie ${ }^{\mathrm{a}, 1}$, Corin V. White ${ }^{\mathrm{a}, \mathrm{b}, 1}$, Hanna Retallack, Wesley Wu ${ }^{\mathrm{a}}$, Matthew S. Moser ${ }^{c}$, Judy Sakanari ${ }^{c}$, Kenny Ang ${ }^{d}$, Christopher Wilson ${ }^{d}$, Michelle R. Arkin ${ }^{d}$, Joseph L. DeRisi ${ }^{\mathrm{a}, \mathrm{e}, \#}$

${ }^{1}$ These authors contributed equally to this work

aDepartment of Biochemistry and Biophysics, University of California San Francisco, San Francisco, California, USA

${ }^{\mathrm{b}}$ California State University Monteray Bay, Seaside, California, USA

'Department of Pharmaceutical Chemistry, University of California San Francisco, San Francisco, California, USA

${ }^{\mathrm{d} S}$ Small Molecule Discovery Center, University of California San Francisco, San Francisco, California, USA

${ }^{\mathrm{e}}$ Chan Zuckerburg Biohub, San Francisco, California, USA

\#Corresponding author (joe@derisilab.ucsf.edu) 


\section{Abstract}

Balamuthia mandrillaris is a pathogenic free-living amoeba that causes a rare but almost always fatal infection of the central nervous system called granulomatous amoebic encephalitis (GAE). Two distinct forms of $B$. mandrillaris - a proliferative trophozoite form and a non-proliferative cyst form, which is highly resistant to harsh physical and chemical conditions - have been isolated from environmental samples worldwide and are both observed in infected tissue. Patients suffering from GAE are typically treated with aggressive and prolonged multi-drug regimens often including the antimicrobial agents miltefosine and pentamidine isethionate. However, survival rates remain low and studies evaluating the susceptibility of $B$. mandrillaris to these compounds and other potential therapeutics are limited. To address the need for more effective treatments, we screened 2,177 clinically-approved compounds for in vitro activity against $B$. mandrillaris. The quinoline antibiotic nitroxoline, which has safely been used in humans to treat urinary tract infections, was identified as a lead compound. We show that nitroxoline inhibits both trophozoites and cysts at low micromolar concentrations, which are within a physiologically relevant range. We compare the in vitro efficacy of nitroxoline to drugs currently used in the standard of care for GAE and find that nitroxoline is the most potent and selective inhibitor of $B$. mandrillaris tested. Furthermore, we demonstrate that nitroxoline prevents $B$. mandrillaris-mediated destruction of host cells in cultured fibroblast and primary brain explant models also at physiologically relevant concentrations. Together, our findings indicate that nitroxoline is a promising candidate for repurposing as a novel treatment of $B$. mandrillaris infections. 


\section{Importance}

Balamuthia mandrillaris is responsible for hundreds of reported cases of amoebic encephalitis, the majority of which have been fatal. Despite being an exceptionally deadly pathogen, B. mandrillaris is understudied, leaving many open questions regarding epidemiology, diagnosis, and treatment. Due to the lack of effective drugs to fight $B$. mandrillaris infections, mortality rates remain high even for patients receiving intensive care. This study addresses the need for new anti-amoebic drugs using a high-throughput screening approach to identify novel B. mandrillaris inhibitors. The most promising candidate identified was the quinoline antibiotic nitroxoline, which has a long history of safe use in humans. We show that nitroxoline kills $B$. mandrillaris at physiologically relevant concentrations and exhibits greater potency and selectivity than drugs commonly used in the current standard of care. The findings we present demonstrate the potential of nitroxoline to be an important new tool in the treatment of life threatening $B$. mandrillaris infections.

\section{Introduction}

The opportunistic protist pathogen, Balamuthia mandrillaris causes rare but life threatening infections of the central nervous system (CNS), termed Balamuthia or granulomatous amoebic encephalitis (GAE) $(1,2)$. Onset of the disease is gradual and chronically develops over a few weeks to months in both immunocompromised and immunocompetent individuals worldwide $(1,3)$. Presenting clinical symptoms include but are not limited to fever, vomiting, neck 
stiffness, headache, nausea, personality changes, and seizures $(1,3)$. These symptoms are nonspecific, overlapping with symptoms caused by more common brain infections such as bacterial and viral meningitis as well as non-infectious neuroinflammatory syndromes. Cutaneous presentation is less common and can produce symptoms ranging from painless swelling to ulceration and formation of large lesions (4-6). Infections involving other organs ranging from the lungs to the eye have also been documented $(7,8)$. Thus, B. mandrillaris-induced encephalitis often goes unrecognized and diagnosis is frequently only made postmortem. Several hundred cases have been reported, however, the actual disease burden is likely underestimated $(2,9)$.

While systematic ecological studies of $B$. mandrillaris have not been performed, free-living B. mandrillaris have been isolated from water, soil, and dust across all continents (10-18). Cases of human and animal infections are also reported on all continents but are most common in South America and the southern United States (reviewed in Bravo and Seas, 2012; H Diaz, 2011; and Centers for Disease Control (CDC) 2008) (19-35). B. mandrillaris is thought to be transmitted by inhalation of contaminated aerosols or exposure via broken skin (36). Fatal amoebic encephalitis has also occurred after solid organ transplantation $(37,38)$. Pathogenesis is believed to involve hematogenous spread to the CNS through penetration of the blood-brain barrier and amoebae are frequently observed around blood vessels $(3,36)$. 
Free-living amoebae such as Sappinia diploidea, Acanthamoeba spp. and Naegleria fowleri can also cause infection of the CNS with very poor prognosis $(2,39)$. Acanthamoeba and Balamuthia are the most similar and are classified in the same eukaryote super group Amoebozoa: Acanthamoebidae (40). The mode of infection employed by Sappinia diploidea and Acanthamoeba spp. is thought to be similar to Balamuthia, as encephalitis caused by these genera progresses over several weeks to months and is associated with water or soil contact. On the other hand, acute encephalitis caused by $N$. fowleri is distinct and specifically associated with recreation in warm freshwater environments with presumed neuroinvasion of the amoeba by passing up the nose through the cribiform plate to the brain. All of these pathogenic amoebae have a proliferative trophozoite form and a dormant, thick-walled cyst form; the cyst form is notoriously more resistant to antimicrobials (41-46) and a variety of abiotic stressors such as ultraviolet light (47-49). Such attributes, along with the fact that drug sensitivities differ among genera, species, and strains of free-living amoebae have complicated studies in drug discovery (50).

Infection of the CNS by B. mandrillaris is almost always fatal and no specific and highly successful treatment regimen is known $(44,51)$. The CDC recommends the following drugs for treatment of $B$. mandrillaris CNS infection: pentamidine isethionate, miltefosine, fluconazole, flucytosine, sulfadiazine, azithromycin and/or clarithromycin (52). In vitro studies with the CDCrecommended drugs show little to no inhibition of amoebic growth by fluconazole, 
sulfadiazine and flucytosine while azithromycin, pentamidine isethionate, miltefosine, and voriconazole (fluconazole derivative) exhibit amoebicidal or amoebistatic activity $(11,41,50)$. Current treatments for $B$. mandrillaris CNS infections employing experimental combinations of these drugs have produced inconsistent outcomes including survival in some cases and fatality in others (7, $19,23,27,29,30,34,53-61)$. As the efficacy and specificity of current treatments remains uncertain, there is a clear need to identify additional drugs that can improve patient outcomes.

The goal of this study was to identify, from a set of clinically-approved compounds, candidates that have the potential to be repurposed for treatment of B. mandrillaris infections. Here, we screened a library of 2,177 clinicallyapproved compounds and found that the quinoline antibiotic nitroxoline (8hydroxy-5-nitroquinoline) exhibits amoebicidal activity at low micromolar concentrations, well within the range of estimated plasma concentrations achieved with recommended oral dosing (62-64). Through direct in vitro comparisons, we find that nitroxoline is a substantially more potent and selective inhibitor of $B$. mandrillaris than three commonly used GAE treatments currently recommended by the CDC. In addition to killing B. mandrillaris trophozoites, nitroxoline also causes encystment and substantially delays recrudescence of active amoebae, which is significant considering the rapid decompensation of patients suffering from GAE. Nitroxoline, with its ease of delivery and favorable 
pharmacodynamic properties, has the potential to be an effective treatment for GAE in singularity or in combination with drugs in the current standard of care.

\section{Methods}

\section{Human Cell Lines}

Hep-G2 (ATCC HB-8065), U87 (gift of Jonathan Weissman lab), H4 (ATCC HTB-148), and HEK-293T (ATCC CRL-3216) cells were cultured in Dulbecco's Modified Eagle's Medium (Gibco) containing 10\% (vol/vol) FBS (Gibco), $2 \mathrm{mM} \mathrm{L-glutamine,} 100 \mathrm{U} / \mathrm{mL}$ penicillin/streptomycin (Gibco), and $10 \mathrm{mM}$ Hepes buffer. HFF-1 cells (ATCC SCRC-1041) were cultured in DMEM containing $15 \% \quad(\mathrm{vol} / \mathrm{vol}) \quad \mathrm{FBS}, \quad 2 \mathrm{mM} \quad$ L-glutamine, $100 \mathrm{U} / \mathrm{mL}$ penicillin/streptomycin, and $10 \mathrm{mM}$ Hepes buffer (Gibco). All mammalian cell incubation steps were carried out at $37^{\circ} \mathrm{C}$ with $5 \% \mathrm{CO}_{2}$. All cell lines were tested for mycoplasma contamination using the Lonza Mycoalert mycoplasma detection kit (Lonza).

\section{Balamuthia mandrillaris propagation, handling and encystment}

Balamuthia mandrillaris (ATCC PRA-291) were maintained axenically in $150 \mathrm{~cm}^{2}$ flasks (Corning) containing modified Cerva's medium (axenic medium) with the following formulation: $20 \mathrm{~g}$ of Bacto Casitone (Difco), $68 \mathrm{~mL}$ of $10 \mathrm{x}$ Hank's balanced salt solution (Gibco), 10\% fetal bovine serum, and $1 \mathrm{x}$ penicillinstreptomycin (200 Ul/mL - $200 \mu \mathrm{g} / \mathrm{mL})$ (65). Axenic growth of $B$. mandrillaris resulted in $2-3 \times 10^{5}$ amoebae/mL in log phase. Following findings of a previous 
study, encystment of $B$. mandrillaris was induced by galactose exposure (66). B. mandrillaris trophozoites were grown to log phase in axenic media and galactose was added to a final concentration of $12 \%(\mathrm{v} / \mathrm{v})$. Amoebae were cultured in the induction medium until trophozoites were no longer observed (approximately 10 days). Galactose-induced cysts transition back to trophozoites after approximately three days of incubation in galactose-free axenic medium. Therefore, all assays with cysts were completed in the induction medium. To quantify amoebae for use in experiments, actively growing trophozoites or recently induced cysts were centrifuged at 3,000 rpm for 5 minutes, resuspended in axenic medium and counted with a disposable hemocytometer (SKC, Inc.). All incubation steps for $B$. mandrillaris growth were carried out at $37^{\circ} \mathrm{C}$ with $5 \% \mathrm{CO}_{2}$.

\section{Primary drug screening of Balamuthia mandrillaris trophozoites in vitro}

Screening of a clinically-approved library of compounds, compiled by the Small Molecule Discovery Center (SMDC) at the University of California San Francisco was completed at $20 \mu \mathrm{M}$ in $0.2 \%$ DMSO. All 2,177 drugs in this library were stored as $10 \mathrm{mM}$ stocks dissolved in $100 \%$ DMSO (Sigma-Aldrich) at $-20^{\circ} \mathrm{C}$. B. mandrillaris amoebae were resuspended in axenic medium and distributed into opaque 384-well plates (Corning) at a density of 3,000 amoebae per well using a BioMek NX liquid handler. Negative control wells were treated with vehicle only (0.2\% DMSO in axenic medium) and positive control wells simulating total destruction of amoebae were seeded with amoeba lysate generated by 3 consecutive freeze-thaw cycles. Following 72 hours of incubation, $30 \mu \mathrm{L}$ of 
CellTiter Glo reagent (CTG; Promega) was added to each well. The luminescence was measured with a Promega GloMax-Multi+ plate reader at 2, 4, and 8 hours after CTG addition. The percent inhibition of $B$. mandrillaris was calculated based on the CTG luminescence measurements of treated wells relative to both positive and negative controls using the following equation: \% inhibition $=100-100^{*}($ (test well intensity - positive control intensity $) /($ negative control - positive control)). The B-Score, a plate-based statistical approach for correcting row, column, and edge effects, was also calculated for each compound in the library (67). Raw luminescence measurements and computed inhibition values are displayed in Table S1A. Hits were determined to be compounds with a B-score of approximately 5 or above and percent inhibition of approximately $40 \%$ or above (Table S1B). Hit compounds that are approved only for topical administration or veterinary use were not tested in secondary screening (highlighted in yellow in Table S1B and Fig 1B). Compounds identified in the primary screen that did not exhibit activity upon repurchase of fresh compound were removed from consideration in the screening funnel.

\section{Secondary drug screening against $B$. mandrillaris trophozoites, HFF-1 and}

\section{H4 human cells in vitro}

Secondary screening of hit compounds consisted of dose-response experiments to measure the toxicity of each compound to $B$. mandrillaris trophozoites, HFF-1 human fibroblast cells, and H4 human neuroglioma cells. Four 384-well plates were prepared prior to drug addition: one opaque plate 
(Corning) seeded with 3,000 HFF-1 cells per well in $60 \mu \mathrm{L}$ complete media, one opaque plate seeded with $2,000 \mathrm{H} 4$ cells per well in $60 \mu \mathrm{L}$ complete media, one opaque plate containing $30 \mu \mathrm{L}$ axenic media, and one clear plate (Corning) containing $30 \mu \mathrm{L}$ axenic media. Opaque plates were used to measure the viability of trophozoites using the CTG assay and clear plates were used for microscopic examination of cyst formation. HFF-1 and H4 plates were seeded 24 hours prior to drug addition. The selected primary screen hits were added from $10 \mathrm{mM}$ DMSO stocks into wells of all four test plates to reach final concentrations ranging from $0.06 \mu \mathrm{M}$ to $30 \mu \mathrm{M}$ (10 concentrations, 2-fold serial dilution). Negative control wells received concentrations of DMSO corresponding to the amount of DMSO in each tested drug well (reaching a maximum of $0.3 \%$ DMSO). B. mandrillaris trophozoites were resuspended in axenic media and added to the plates containing drug dilutions in axenic media at a density of 3,000 amoebae per well in a final volume of $60 \mu \mathrm{L}$ media. All plates were incubated for 72 hours. Throughout the incubation period, the clear-bottom B. mandrillaris plate was monitored for large-scale changes to population encystment in response to drug treatment. After the 72 hour incubation, $30 \mu \mathrm{L}$ of CTG reagent was added to all wells of the opaque assay plates and luminescence was measured with a Promega GloMax-Multi+ plate reader at 2, 4, and 8 hours after CTG addition. $I_{50}$ values for inhibition of $B$. mandrillaris viability were determined using GraphPad Prism 4-parametric sigmoidal curve fitting model, with bottom and top constraints set to 0 and 1 respectively (Table S1C). 


\section{Nitroxoline structure-activity-relationship experiments}

Nineteen commercially available analogs of nitroxoline were selected for structure-activity-relationship (SAR) experiments based on variance in functional groups that may play a role in the observed mechanism of action (compound sourcing and data in Table S2). B. mandrillaris were grown to log phase axenically and plated at 4,000 amoebae per well in opaque 96-well plates. Each nitroxoline analog was dissolved in $100 \%$ DMSO at $10 \mathrm{mM}$. Analog stocks were serially diluted in water to generate 8-point dilution series, which were then used to treat assay wells containing B. mandrillaris trophozoites at final concentrations ranging from $0.14 \mu \mathrm{M}$ to $300 \mu \mathrm{M}$ (8 concentrations, 3-fold serial dilution) in a final volume of $100 \mu \mathrm{L}$. After incubation for 72 hours, $50 \mu \mathrm{L}$ of CTG was added to all assay wells. Luminescence was measured using the Promega GloMax Multi+ luminometer 2, 4, and 8 hours after CTG addition. $I_{50}$ values were determined using GraphPad Prism 4-parametric sigmoidal curve fitting model with bottom and top constrains of 0 and 1 , respectively.

Dose-response experiments with HFF-1, H4, U87, Hep-G2, HEK 293T cells and Balamuthia mandrillaris trophozoites and cysts

B. mandrillaris trophozoites were seeded at 4,000 amoebae per well into opaque and clear bottom 96-well plates (Corning). Homogenous populations of B. mandrillaris cysts generated by galactose induction were seeded at 4,000 amoebae per well into opaque 96-well plates. HFF-1 (fibroblast), H4 (glial), U87 (glial), HEK-293T (kidney), and Hep-G2 (liver) were seeded at 3,000 cells per 
well in opaque 96-well plates 24 hours prior to addition of drug. Stocks of nitroxoline (Selleck Chemicals) were dissolved in 100\% DMSO at $10 \mathrm{mM}$. Stocks of azithromycin (Selleck Chemicals), pentamidine isethionate (Selleck Chemicals), and miltefosine (Selleck Chemicals) were dissolved in water at 10 $\mathrm{mM}$. Drug stocks were serially diluted in water to generate 12-point dilution series, which were then used to treat assay wells containing B. mandrillaris or human cells at final concentrations ranging from $0.39 \mu \mathrm{M}$ to $400 \mu \mathrm{M}$ in $100 \mu \mathrm{L}$ total well volume. Control wells were treated with vehicle (DMSO or water) at concentrations corresponding to the final vehicle concentrations in each drug dilution series. After incubation for 72 hours, $50 \mu \mathrm{L}$ of CTG was added to all assay wells. Luminescence was measured with a Promega GloMax-Multi+ plate reader 2, 4, and 8 hours after CTG addition. All dose-response experiments were performed with at least three independent biological replicates. $I_{50}$ values were determined as previously described. To quantify encystment in treated and untreated conditions, amoebae in individual assay wells were resuspended thoroughly and the number of cysts and trophozoites in $10 \mu \mathrm{L}$ samples were counted by hemocytometer (SKC, Inc.). Cysts and trophozoites are morphologically distinct, making them simple to distinguish with brightfield microscopy (example images shown in Fig. S1). Encystment assays were performed with three independent biological replicates.

\section{Balamuthia mandrillaris recrudescence assays}


Populations of $B$. mandrillaris were diluted to $2.5 \times 10^{5}$ amoebae in $10 \mathrm{~mL}$ media and were treated with $3.5,7,14,28,56,84$, and $112 \mu \mathrm{M}$ nitroxoline, pentamidine isethionate or miltefosine and incubated for 72 hours. Following incubation, all remaining amoebae in each population (various mixtures of cysts and trophozoites) were pelleted at 3,000 rpm for 5 minutes and resuspended in drug-free HFF-1 medium. Each resuspended B. mandrillaris population was placed on a monolayer of HFF-1 cells that were seeded at $10^{6}$ cells per flask in $10 \mathrm{~mL} 24$ hours prior to inoculation. At this cell density, untreated amoebae typically consume $100 \%$ of HFF-1 monolayers within 24 hours. Co-culture flasks containing amoebae and HFF-1 cells were incubated until $100 \%$ of the HFF-1 monolayer was consumed as observed by daily microscopic inspection or until the pre-determined endpoint of the experiment at 28 days post- $B$. mandrillaris inoculation. The day on which complete clearance of HFF-1 monolayer occurred was recorded for all conditions. All recrudescence assays were performed with three independent biological replicates. These methods were adapted from a minimum trophozoite amoebicidal concentration (MTAC) assay that was conducted with monolayers of MA104 monkey kidney cells (41).

\section{Primary brain tissue model}

De-identified tissue samples were collected with previous patient consent in strict observance of the legal and institutional ethical regulations. Protocols were approved by the Human Gamete, Embryo, and Stem Cell Research Committee (institutional review board) at the University of California, San 
Francisco. Primary brain tissue samples were sectioned perpendicular to the ventricle to obtain slices $300 \mu \mathrm{m}$ thick and $\sim 2.5 \mathrm{~mm}^{2}$ in surface area, using a Leica VT1200S vibrating blade microtome in artificial cerebrospinal fluid containing $125 \mathrm{mM} \mathrm{NaCl}, 2.5 \mathrm{mM} \mathrm{KCl}, 1 \mathrm{mM} \mathrm{MgCl} 2,1 \mathrm{mM} \mathrm{CaCl}, 1.25 \mathrm{mM}$ $\mathrm{NaH}_{2} \mathrm{PO}_{4}$. Explants were transferred to slice culture inserts (Millicell) in 6-well culture plates and cultured with media containing 66\% Eagle's Basal Medium, $25 \%$ Hanks balanced salt solution, $5 \%$ fetal bovine serum, $1 \% \mathrm{~N}-2$ supplement, 1x penicillin-streptomycin, and glutamine, in a $37^{\circ} \mathrm{C}$ incubator with $5 \% \mathrm{CO}_{2} .12$ hours after plating, slices were inoculated with $10^{4} \mathrm{~B}$. mandrillaris trophozoites in $20 \mu \mathrm{L}$ of complete media containing vehicle (DMSO) or $35 \mu \mathrm{M}$ nitroxoline, added dropwise to the slice surface. Media below the cell culture insert was adjusted to matching vehicle or nitroxoline concentrations. At 20 hours post-inoculation, media below the cell culture insert was replaced with fresh media containing no drug. At this time, amoeba on top of the insert surrounding and within the tissue were undisturbed. Brightfield and phase contrast images were captured during the live culture experiment at $4 \mathrm{X}, 10 \mathrm{X}$, and 20X using an Evos FL Cell Imaging System. At 4 days post-inoculation, slices were gently fixed in $3.7 \%$ PFA for 4 hours at $4^{\circ} \mathrm{C}$, then rinsed with PBS and stained for 2 hours at room temperature with DAPI $(0.3 \mu \mathrm{M})$ in PBS with $1 \%$ Triton $\mathrm{X}-100$, and then mounted with ProLong Gold Antifade Mountant (Thermo). Images of stained tissue were obtained with a Nikon Ti spinning disk confocal microscope at 20X magnification. Confocal z-stacks were projected and adjusted in ImageJ. Brightfield images 
were stitched using photomerge in Photoshop (Adobe). Brightfield time-lapse images were processed as movies in ImageJ.

\section{Results}

Identification of nitroxoline as an inhibitor of B. mandrillaris trophozoites in vitro

Due to the extremely high mortality rate associated with Balamuthia mandrillaris infections and the limited efficacy of current treatments, there is a clear need to identify additional therapeutic strategies to improve patient outcomes in these rare, but deadly infections. Here, we established replicating axenic cultures of $B$. mandrillaris (ATCC PRA-291) and screened 2,177 clinicallyapproved compounds for reduction of trophozoite viability following 72 hours of treatment at $20 \mu \mathrm{M}$. Compounds with high percent inhibition ( $40 \%$ or above) and B-score ( $\sim 5$ or above) were nominated for secondary screening (Fig. 1A, Table S1A). Remaining compounds were annotated by class and delivery method to eliminate drugs only approved for topical delivery or veterinary use, which have low therapeutic potential (Table S1B). The selected candidate drugs were tested in dose-response assays with $B$. mandrillaris trophozoites as well as HFF-1 and $\mathrm{H} 4$ human cell cultures to confirm their activity and evaluate toxicity to human cells (Table S1C). Half-maximal inhibitory concentration $\left(\mathrm{IC}_{50}\right)$ values indicated that only two compounds, pentamidine isethionate and nitroxoline, demonstrated adequate potency against $B$. mandrillaris without high toxicity to human cells. Since the amoebistatic activity of pentamidine has previously been 
described (45), we focused on further characterizing the novel activity of nitroxoline as the lead compound identified by this screen.

\section{Nitroxoline structure-activity-relationship experiments}

Nitroxoline is currently in clinical use as an antimicrobial drug in certain European and Asian countries. The hypothesized mechanism of action (MoA) is as a metal chelator that disrupts biofilm formation (68). Nitroxoline and other 8hydroxyquinolines have also previously demonstrated in vitro anticancer activity and free-radical metabolites are thought to be involved in cell death (69). To test which of these mechanisms is applicable in killing B. mandrillaris, we tested 19 commercially available analogs of nitroxoline for amoebicidal activity. While nitroxoline itself remained the most potent compound tested, there was a clear necessity for the 8-position hydroxyl group on the quinoline ring to retain high activity (Fig. 2, Table S2). As demonstrated by the activity of 8-hydroxyquinoline [2], the 5-position nitro group is not necessary for activity, while in contrast, retaining the nitro group without the hydroxy group [3] significantly decreases activity. Replacing the nitro group at the 5-position of the 8-hydroxyquinoline core with a variety of other functional groups, along with dual 5,7-position functionalization (compounds 4-13) results in several active but less potent analogs with no clear trend due to aromatic electronic affects. The sulfonic acid functionalized variant [13] was the sole inactive compound among compounds 413, which we speculate may be due to differences in uptake or permeability. Lastly, phenanthroline [14], a structurally similar bidentate metal binding ligand, 
also demonstrated activity against $B$. mandrillaris. Taken together, these results indicate a likely metal binding mechanism for the original nitroxoline compound.

\section{Direct comparison of nitroxoline to standard-of-care drugs for GAE treatment}

To evaluate nitroxoline as a potential drug to treat $B$. mandrillaris infections, we compared the in vitro performance of nitroxoline to pentamidine isethionate, miltefosine, and azithromycin, three drugs recommended by the CDC and commonly used in treatment of GAE (52). We performed side-by-side dose-response experiments to measure the efficacy of each drug against $B$. mandrillaris trophozoites and the toxicity to different human cell types using the following cell lines: HFF-1 (fibroblast), H4 (glial), U87 (glial), HEK-293T (kidney), and Hep-G2 (liver). Nitroxoline was the most potent inhibitor of $B$. mandrillaris trophozoites with an $\mathrm{IC}_{50}$ of $2.84 \mu \mathrm{M}$, compared to $\mathrm{IC}_{50}$ values of $9.14 \mu \mathrm{M}, 63.23$ $\mu \mathrm{M}$, and $244.10 \mu \mathrm{M}$ for pentamidine, miltefosine, and azithromycin, respectively (Fig. 3A). Nitroxoline was also the only drug with an $\mathrm{IC}_{50}$ against $B$. mandrillaris that was lower than the half-maximal cytotoxic concentration $\left(\mathrm{CC}_{50}\right)$ for all cell lines tested. The average $\log _{10}$ selectivity index $\left(\mathrm{CC}_{50}\right.$ for human cell toxicity/IC $\mathrm{C}_{50}$ for B. mandrillaris inhibition) of nitroxoline across all cell lines was 0.832 , compared to $0.049,-0.102$, and -0.409 for pentamidine, miltefosine, and azithromycin, respectively (Fig. 3B).

\section{Encystment response of $B$. mandrillaris}


In addition to dose-dependent reduction in $B$. mandrillaris trophozoite viability, we also observed a general increase in the ratio of cysts to trophozoites correlated with increasing concentration of some drugs. We investigated the propensity of nitroxoline, pentamidine isethionate, miltefosine, and azithromycin to induce encystment of $B$. mandrillaris by counting the number of cysts and trophozoites in culture samples following 72 hours of treatment with different drug concentrations. We observed a dose-dependent reduction in the number of trophozoites in the population for all four drugs. Nitroxoline and pentamidine isethionate caused an increase in both the total number and the proportion of cysts in the population, while no substantial number of cysts was observed at any concentration of miltefosine or azithromycin (Fig. 4A-D). Because encystment appears to occur as a response to certain drug treatments, we also assessed the ability of each drug to inhibit the viability of pre-formed B. mandrillaris cysts. We induced encystment by sustained exposure to $12 \%$ galactose and conducted dose-response viability measurements for each drug. Nitroxoline was again the most potent inhibitor of cysts with an $\mathrm{IC}_{50}$ of $15.48 \mu \mathrm{M}$ compared to $\mathrm{IC}_{50}$ values of 26.26 $\mu \mathrm{M}, 76.48 \mu \mathrm{M}$, and $788.4 \mu \mathrm{M}$ for pentamidine, miltefosine, and azithromycin, respectively (Fig. 4E). While nitroxoline, pentamidine, and azithromycin were considerably less potent inhibitors of cyst viability compared to trophozoites (Fig. 3A), miltefosine inhibited both forms of $B$. mandrillaris at similar concentrations.

\section{Delayed recrudescence of $B$. mandrillaris treated with nitroxoline}


Nitroxoline and the tested standard-of-care drugs induce various combinations of distinct and intermediate B. mandrillaris phenotypes including death and encystment. Though it is assumed that drug-induced phenotypes such as encystment affect the rate of amoeba population growth and host cell destruction, the magnitude and duration of these effects are unknown. To assess how rapidly amoeba populations recover and proliferate following drug treatment, we developed a recrudescence assay wherein we treated $B$. mandrillaris trophozoite cultures with varying concentrations of nitroxoline, pentamidine, or miltefosine for 72 hours, removed drug, and then added the remaining amoebae to a monolayer of HFF-1 cells in the absence of drug. The post-treatment recovery time was measured as the number of days required for each $B$. mandrillaris population to clear $100 \%$ of the host cells. Treatments that completely eliminated B. mandrillaris populations were determined by observing no live trophozoites or destruction of host cells at any point during the 28 day experiment. We found that $7 \mu \mathrm{M}$ and $14 \mu \mathrm{M}$ pentamidine delayed recovery of $B$. mandrillaris by $1-2$ weeks, but increasing the dose from $14 \mu \mathrm{M}$ to $56 \mu \mathrm{M}$ only delayed recovery by an additional 3 days. Consistent with the steep Hill slope observed in dose-response experiments, miltefosine caused very little delay to clearance time at $56 \mu \mathrm{M}$ but completely eliminated $B$. mandrillaris populations at $84 \mu \mathrm{M}$. In contrast, nitroxoline delayed amoeba recovery by 2-3 weeks at low micromolar concentrations and completely eliminated B. mandrillaris populations at $28 \mu \mathrm{M}$. 


\section{Protective effect of nitroxoline in a primary human brain tissue model}

Findings from the recrudescence assays suggest that nitroxoline treatment may significantly impede destruction of host cells in the context of $B$. mandrillaris infection. To further explore this possibility, we performed experiments modeling B. mandrillaris infection and nitroxoline treatment in primary human brain tissue. Human cortical tissue slices were exposed to $B$. mandrillaris trophozoites and simultaneously treated with nitroxoline or vehicle (DMSO) for 20 hours before media was changed to remove drug or vehicle. Tissues were cultured for 4 days and then evaluated for damage by microscopic examination (Fig. 5 and S2). Untreated tissues show widespread damage following B. mandrillaris exposure including loss of distinct tissue edges and reduction of cell density (Fig. 5B). Large numbers of highly motile B. mandrillaris trophozoites can be seen at the edges of tissues and intermixed with human cells (Movie S1). In contrast, nitroxoline treated tissues did not show signs of $B$. mandrillaris-mediated destruction and appeared similar to uninfected tissues (Fig. 5A and C). Cysts with little to no motility are observed outside the boundaries of tissues (Movie S2). While these findings are qualitative, the largescale differences in tissue morphology observed in this experiment are consistent with the possibility that nitroxoline has a protective effect towards host tissue in the context of $B$. mandrillaris infection.

\section{Discussion}

GAE caused by Balamuthia mandrillaris is almost always fatal (19-34). 
Because there is no established treatment for GAE, patients commonly receive experimental combinations of antimicrobial agents in aggressive and prolonged treatment regimens with mixed outcomes $(7,19,23,27,29,30,34,53-61)$. In the present study, we aimed to address the critical need for new treatments of GAE by identifying novel amoebicidal compounds amongst known drugs using a high-throughput screening approach. Because our goal was to identify candidate drugs with established safety and pharmacodynamic profiles, we chose to screen a library of 2,177 clinically-approved compounds. Based on the criteria of B-score and percent inhibition of $B$. mandrillaris viability, we selected 12 compounds from the primary screen for follow-up screening (Fig. 1A, Table S1B). Secondary screening eliminated all candidate compounds on the basis of low potency for inhibition of $B$. mandrillaris or high toxicity to human cells with the exception of the quinoline antibiotic nitroxoline. Nitroxoline demonstrated promising potency and selectivity for B. mandrillaris inhibition, which led us to focus our efforts on further investigating its novel amoebicidal activity.

We performed side-by-side experiments to directly compare the in vitro efficacy of nitroxoline for $B$. mandrillaris inhibition to the efficacy of pentamidine isethionate, miltefosine, and azithromycin, three drugs recommended by the CDC for treatment of GAE and commonly used in case reports $(29,30,52-54$, 56). We found that nitroxoline was the most potent inhibitor of $B$. mandrillaris trophozoite viability with an $\mathrm{IC}_{50}$ of $2.84 \mu \mathrm{M}$ and $\mathrm{IC}_{99}$ of $7.54 \mu \mathrm{M}$ (Fig. 3A). To estimate the selectivity of each drug, we also measured the toxicity of each 
compound to five different human cell lines. For pentamidine, miltefosine, and azithromycin, drug concentrations that reduced $B$. mandrillaris viability also caused significant toxicity to human cells, giving very small selectivity indices (Fig. 3B). In contrast, nitroxoline had an $\mathrm{IC}_{50}$ for B. mandrillaris inhibition that was lower than the $\mathrm{CC}_{50}$ for all cell lines tested and had the largest mean selectivity index.

B. mandrillaris and other free-living amoebae have a dormant, thick-walled cyst form which is highly resistant to several types of environmental stress including exposure to some compounds that are toxic to the trophozoite form (44, $45,47,49)$. A previous study postulates that the transition from the trophozoite form to the cyst form can be triggered by a variety of conditions including chemical stress (70), raising the possibility that treatment with amoebicidal or amoebistatic drugs may induce encystment. To investigate this possibility, we quantified the frequency of cysts observed in $B$. mandrillaris populations treated with different drug concentrations. We observed that low micromolar doses of nitroxoline and pentamidine isethionate caused an increase in the total number and proportion of cysts in B. mandrillaris populations (Fig. 4A and B). In contrast, miltefosine and azithromycin were not observed to induce encystment at any concentration (Fig. 4C and D). These data support the possibility that $B$. mandrillaris encystment occurs as a response to some but not all compounds that are toxic to trophozoites. We suggest that compounds which promote encystment in addition to killing trophozoites may provide additional benefit in the 
context of infection by slowing or halting the rapid tissue destruction by trophozoites.

Because it is common for both cysts and trophozoites to be found in $B$. mandrillaris infected tissue, it is important to understand the efficacy of amoebicidal drugs against both stages (71). To address this question, we performed side-by-side dose-response experiments with homogenous populations of cysts or trophozoites treated with nitroxoline, pentamidine isethionate, miltefosine, and azithromycin. We found that cysts were less sensitive than trophozoites to all four drugs (Fig. 4E). The difference in sensitivity was marginal for miltefosine and greatest for nitroxoline, which had an $\mathrm{IC}_{50}$ for cyst inhibition 6-fold higher than the $\mathrm{IC}_{50}$ for trophozoite inhibition. Despite being less potent against the cyst form, nitroxoline still exhibited the lowest $\mathrm{IC}_{50}$ for cyst inhibition of all drugs tested at $15.48 \mu \mathrm{M}$.

Viability measurements of drug treated $B$. mandrillaris cultures reflect a complex population phenotype that includes varying degrees of both death and encystment. These measurements are not sufficient to predict the rate at which populations will recrudesce following treatment, which is an important factor in evaluating the overall efficacy of different treatments. We chose to address this aspect of treatment efficacy by performing recovery assays in which $B$. mandrillaris populations were exposed to various drug treatments, removed from drug, and then co-cultured with monolayers of human cells until the host cells 
were fully consumed. As predicted, increasing drug doses caused greater delays to B. mandrillaris recrudescence and host cell destruction (Table 1). Surprisingly, even low micromolar doses of nitroxoline near the $\mathrm{IC}_{50}$ for trophozoite inhibition delayed B. mandrillaris-mediated host cell destruction by 2-3 weeks. This assay also served as a sensitive method to detect very low numbers of surviving amoebae due to the large population expansion occurring over the 28-day experiment duration. Importantly, this sensitive assay allowed us to infer that $B$. mandrillaris populations had been completely eliminated by drug treatment when we observed no signs of amoeba population recovery after 28 days of co-culture with host cells.

Using this method, we determined that doses of $28 \mu \mathrm{M}$ nitroxoline and 112 $\mu \mathrm{M}$ miltefosine completely eliminated $B$. mandrillaris populations. These data are consistent with viability inhibition experiments in indicating that nitroxoline is the most potent inhibitor of $B$. mandrillaris tested. The promising results of this experiment suggest that nitroxoline may be able to fully eliminate $B$. mandrillaris infection if high enough concentrations are reached and is likely to cause substantial delays to host tissue damage even at lower concentrations. This is supported by our findings that nitroxoline prevents $B$. mandrillaris activity and tissue destruction in a primary human brain tissue model (Fig. 5, Movie S1 and S2). Together, these findings suggest that nitroxoline substantially impedes host tissue destruction by $B$. mandrillaris in vitro. Given the rapid progression of 
pathogenesis that is characteristic of GAE, any impediment to tissue destruction could significantly improve patient prognosis.

The pharmacokinetic properties of nitroxoline suggest further promise for its therapeutic value as an inhibitor of $B$. mandrilliaris. Nitroxoline has been safely used for over 50 years in the treatment of urinary tract infections with minimal adverse effects reported (72). Nitroxoline is available in oral and intravenous administration and is typically dosed at $600-800 \mathrm{mg} /$ day for adults, resulting in maximal plasma concentrations $\left(C_{\max }\right)$ up to approximately $30 \mu \mathrm{M}(5.6 \mathrm{mg} / \mathrm{L})$ (62-64), which is 10 -fold higher than the $\mathrm{IC}_{50}$ for $B$. mandrillaris trophozoites in vitro (Fig. 3A). Although the extent to which nitroxoline crosses the blood brain barrier is unknown, a recent study shows that systemically delivered nitroxoline exhibits efficacy against gliomas in mice, implying that efficacious concentrations reached the brain in this model (73). In addition, we previously noted that $B$. mandrillaris frequently causes a necrotizing vasculitis in the CNS with extensive BBB breakdown $(3,36,56)$. As a result, the bioavailability of nitroxoline in the CNS will almost certainly be significantly increased in patients actively suffering from GAE. Furthermore, given the extreme severity of GAE, intrathecal drug delivery can be performed to maximize drug concentrations reaching the brain ( 2 , 74). While many variables may affect the in vivo efficacy of nitroxoline as well as the concentrations that can be achieved in relevant compartments, the literature suggests that the in vitro efficacious concentrations we demonstrate are well within a physiologically relevant range. 
The data presented in this study strongly indicate that nitroxoline warrants further investigation as a potential treatment for B. mandrillaris infections. As an approved compound with an established safety profile (72), nitroxoline may be rapidly deployed as an experimental treatment in dire cases of GAE. In particular, since the current standard of care generally consists of experimental combinations of several antimicrobial agents, adding nitroxoline to these regimens may be a reasonable step in the effort to improve patient prognosis. Although our SAR experiments did not identify any analog that matched the potency of nitroxoline, medicinal chemistry optimization may still be beneficial for a better understanding of possible mechanisms of action and efforts to improve drug specificity. The similarity of $B$. mandrillaris to other free-living amoebae such as Acanthamoeba spp. and Naegleria fowleri raises the intriguing possibility that nitroxoline or related compounds may also have activity against these pathogens. 


\section{Author contributions}

Study design and conception: MTL, CVW, JLD

Data acquisition: MTL, CVW, HR, MSM

Data analysis and interpretation: MTL, CVW, HR, WW, JS, HA, CW, MRA, JLD

Drafting of manuscript: MTL, CVW, JS, and JLD

Critical revision of manuscript: All authors

\section{Acknowledgements}

We thank Jiri Gut for critical advice regarding the axenic culture of Balamuthia

mandrillaris. We are grateful to Galina Schmunk, Tom Nowakowski, and Arnold Kriegstein for their assistance with human tissue experiments. We thank Michael Wilson for helpful discussion and critical reading of the manuscript. 


\section{Figure legends}

Figure 1: (A) Workflow for high-throughput screening of clinically-approved compounds for in vitro activity against $B$. mandrillaris. A primary screen of 2,177 clinically-approved compounds yielded 30 hits meeting the percent inhibition and B-score criteria, of which only 13 candidates were available for oral or IV administration (Fig. 1B). Secondary screening identified only one novel lead compound, nitroxoline, which displayed high selectivity for inhibition of $B$. mandrillaris viability (Table S1C). Structure-activity relationship (SAR) experiments show that 11 of 12 nitroxoline analogs tested with potential metal binding domains remain active against $B$. mandrillaris, suggesting that metal binding plays a role in the mechanism of inhibition by nitroxoline (Fig. 2). Comparison of nitroxoline to three drugs recommended by the CDC for treatment of B. mandrillaris CNS infections (pentamidine isethionate, miltefosine, and azithromycin) indicates that nitroxoline is the most potent and specific inhibitor of B. mandrillaris of the compounds tested (Fig. 3, 4 and Table 1). (B) Plot of percent inhibition relative to untreated controls and B-score measured for each compound in a library of 2,177 clinically-approved compounds. Raw data used to calculate these values is compiled in Table S1A. Drugs recommended by the CDC for treatment of GAE are highlighted in blue. Drugs that are classified as antiseptic, topical, and/or have not been used in humans are shown in yellow. The quinoline antibiotic nitroxoline, which was the top hit identified in this screen, is highlighted in red. 
Figure 2: Structure-activity-relationship experiments suggest that nitroxoline inhibits $B$. mandrillaris through a mechanism related to metal binding. Structures and $\mathrm{IC}_{50}$ values are shown for nitroxoline and select analogs; additional compounds are shown in Table S2. Nitroxoline is made up of a quinoline core with a nitro group at the 5-position and hydroxyl group at the 8-position. Analogs lacking the 8-position hydroxyl group were generally inactive with $\mathrm{IC}_{50}$ values greater than $80 \mu \mathrm{M}$ (e.g. 5-Nitroquinoline [3]). Twelve nitroxoline analogs with predicted metal binding activity were tested and of these, 1,10-phenanthroline [14] and 10 out of 11 compounds with an 8-position hydroxyl group (e.g. 8Hydroxyquinoline [2]) were active with $I_{50}$ values ranging from $17-60 \mu \mathrm{M}$. The only inactive analog with an 8-position hydroxyl group was 8-Hydroxy-5quinolinesulfonic acid [13]. Variance of the 5-position nitro group reduced potency compared to nitroxoline, but no trend related to aromatic electronic effects is apparent.

Figure 3: Potency and selectivity for inhibition of $B$. mandrillaris viability by nitroxoline, pentamidine isethionate, miltefosine, and azithromycin. (A) Doseresponse curves show the effect of nitroxoline (red), pentamidine isethionate (black), miltefosine (blue), and azithromycin (grey) on the viability of $B$. mandrillaris trophozoite populations following 72 hours of treatment. Data points are means and standard errors of at least three independent biological replicates. Nitroxoline is the most potent inhibitor of $B$. mandrillaris viability with an $\mathrm{IC}_{50}$ of $2.84 \mu \mathrm{M}$. (B) Heat map showing the $\log _{10}$ selectivity index (human cell $\mathrm{CC}_{50} / B$. 
mandrillaris $\left.\mathrm{IC}_{50}\right)$ for nitroxoline, pentamidine, isethionate, miltefosine, and azithromycin calculated from the ratio of human cell $\mathrm{CC}_{50}$ to $B$. mandrillaris $\mathrm{IC}_{50}$. Nitroxoline exhibited the greatest mean $\log _{10}$ selectivity index at 0.832 and was the only drug with a positive $\log _{10}$ selectivity index comparing B. mandrillaris inhibition to all cell lines tested.

Figure 4: Relationship of drug treatment to B. mandrillaris encystment. (A-D) Changes in the number of trophozoites (blue) and cysts (red) in B. mandrillaris populations following 72 hours of treatment with various concentrations of nitroxoline $(A)$, pentamidine isethionate $(B)$, miltefosine $(C)$, and azithromycin $(D)$. Low micromolar doses of nitroxoline and pentamidine isethionate cause an increase in the total number of cysts observed in B. mandrillaris populations and an increase in the ratio of cysts to trophozoites. No increase in encystment is observed in B. mandrillaris populations treated with miltefosine or azithromycin. (E) Dose-response curve showing the effect of nitroxoline (red), pentamidine isethionate (black), miltefosine (blue), and azithromycin (grey) on the viability of pre-formed B. mandrillaris cysts. Nitroxoline is the most potent inhibitor of cysts with an $\mathrm{IC}_{50}$ of $15.48 \mu \mathrm{M}$. Compared to trophozoites (Fig. 2A), cysts are substantially less sensitive to all drugs except for miltefosine, which had a similar $I_{50}$ for inhibition of both $B$. mandrillaris forms.

Table 1: Rate of recrudescence and host cell destruction by B. mandrillaris following drug treatment. Cultures of $B$. mandrillaris were exposed to the 
indicated drug concentrations for 72 hours, removed from drug, and transferred to monolayers of human cells where the time until complete monolayer clearance was measured. Mean host cell clearance time is reported as the average of three replicates \pm the standard error. Low micromolar doses of nitroxoline delay $B$. mandrillaris recrudescence by two to three weeks compared to untreated controls. Doses of $28 \mu \mathrm{M}$ nitroxoline and $112 \mu \mathrm{M}$ miltefosine completely prevented recovery of $B$. mandrillaris and damage to host cells throughout the 28-day duration of the experiment.

Figure 5: Nitroxoline prevents $B$. mandrillaris-mediated destruction of human brain tissue explants. Each panel shows an image representative of two tissues 96 hours after exposure to the indicated conditions. Media was changed at 20 hours post-infection to remove nitroxoline or vehicle. (A) Uninfected, untreated (vehicle only) tissues have distinct edges and maintain cell density throughout culture. (B) B. mandrillaris-infected, untreated (vehicle only) tissues show widespread damage, particularly at edges where loss of cell density and disorder of tissue structure is apparent. Large numbers of $B$. mandrillaris trophozoites are observed intermixed with human cells and outside of the tissue (lower half of image). (C) B. mandrillaris-infected tissues treated with $35 \mu \mathrm{M}$ nitroxoline simultaneously with inoculation do not show signs of tissue damage or loss of cell density and maintain distinct edges similar to uninfected tissues. Clusters of B. mandrillaris cysts are observed outside the boundaries of the tissue. 
Table S1: Tabulation of raw data from primary and secondary drug screens. (A) A primary screen of 2,177 clinically-approved compounds measured the decrease in B. mandrillaris trophozoite viability resulting from 72 hours of exposure to $20 \mu \mathrm{M}$ of each compound. Viability for test and control wells was measured using the CellTiter Glo luminescence assay. Raw luminescence intensity values for test wells are reported as well as the average luminescence intensity values for positive and negative controls used for comparison. The Bscore and percent inhibition shown for each compound are calculated using the raw luminescence intensity values. (B) List of compounds meeting loosely applied criteria of B-score of approximately 5 or greater and percent inhibition of approximately 40 or greater. The class and delivery method for each compound is annotated. Compounds that are classified as veterinary or are available only for external/topical administration are highlighted in yellow. Nitroxoline, the top hit compound based on B-score and percent inhibition, is highlighted in red. (C) Secondary screening of hit compounds to determine potency against $B$. mandrillaris trophozoites and toxicity to HFF1 and $\mathrm{H} 4$ human cell lines. All $\mathrm{IC}_{50}$ values were approximated from 8-point dose-response curves. $I_{50}$ values highlighted in red are outside of a desirable range for a hit compound as they indicate either low potency against $B$. mandrillaris $\left(\mathrm{IC}_{50}>30 \mu \mathrm{M}\right)$ or high toxicity to human cells $\left(\mathrm{IC}_{50}<1 \mu \mathrm{M}\right)$. Nitroxoline and pentamidine isethionate were the only compounds that inhibited $B$. mandrillaris trophozoite viability at concentrations similar to or lower than concentrations that were toxic to human cells. 
Table S2: Structures, $\mathrm{IC}_{50}$ values, and dose-response curve fitting parameters for nitroxoline and all nitroxoline analogs tested for activity against $B$. mandrillaris. $\mathrm{IC}_{50}, \mathrm{R}^{2}$, and Hill slope values were calculated based on sigmoidal curves fit to 8-point dose-response experiments performed in triplicate. Compounds 2, 4-12, and 14 were the most potent inhibitors of $B$. mandrillaris, most likely due to the presence of an 8-position hydroxyl group or bidentate ligand on the quinoline ring, which are predicted to be necessary for metal binding.

Figure S1: Example brightfield images of $B$. mandrillaris trophozoites and cysts. (A) Example images show B. mandrillaris trophozoites in log-phase growth. Trophozoites are pleomorphic and can be elongated or generally rounded, often with highly branched pseudopodia. (B) Example images show B. mandrillaris cysts induced by galactose exposure. Cysts are spherical, generally smaller in diameter than trophozoites, and can have visibly distinct layers. Some cysts show signs of vacuolization that may be indicative of cell death.

Figure S2: (A and B) Brightfield images representative of two biological replicates for human brain tissue explants before and after exposure to the indicated conditions. Nitroxoline or vehicle was added simultaneously with $B$. mandrillaris trophozoites and removed after 20 hours. Four days after exposure to $B$. mandrillaris, untreated tissues show widespread damage and loss of cell 
density while nitroxoline treated tissues remain intact and appear similar to uninfected tissues. Large numbers of $B$. mandrillaris trophozoites can be seen at the edges of untreated tissues, while only clusters of cysts are observed in nitroxoline-treated tissues. (C) Images representative of two biological replicates of human brain tissue explants fixed and stained with DAPI four days after exposure to the indicated conditions (two images per condition). The number of host cell nuclei is dramatically reduced in untreated, B. mandrillaris-infected tissues compared to uninfected tissues, whereas B. mandrillaris-infected tissues treated with nitroxoline show no apparent loss of nuclei.

Movie S1: (A) Representative movie showing the edge of an untreated (vehicle only), uninfected primary brain tissue section 4 days after the start of culture. No significant movement of cells is observed and a clearly defined edge marks the border of the tissue. (B and $\mathrm{C}$ ) Representative movies showing edges of two different untreated (vehicle only), B. mandrillaris-infected primary brain tissue sections 4 days after inoculation of amoebae. Highly motile B. mandrillaris trophozoites are observed throughout the field of view and the tissue edges are not discernable due to loss of host cell density. (D and E) Representative movies showing edges of two different nitroxoline treated, B. mandrillaris-infected primary brain tissue sections 4 days after inoculation of amoebae. Tissues were treated with $35 \mu \mathrm{M}$ nitroxoline simultaneously with amoebae inoculation. Nonmotile $B$. mandrillaris cysts are observed individually primarily at the edge of the 
bioRxiv preprint doi: https://doi.org/10.1101/331785; this version posted June 6, 2018. The copyright holder for this preprint (which was not certified by peer review) is the author/funder, who has granted bioRxiv a license to display the preprint in perpetuity. It is made available under aCC-BY-NC-ND 4.0 International license.

Laurie and White et al., Inhibition of Balamuthia mandrillaris by nitroxoline

tissue (D) and in clusters outside the tissue (E). The tissue edges are intact and do not show signs of host cell destruction by B. mandrillaris. 


\section{References}

1. Schuster FL, Yagi S, Gavali S, Michelson D, Raghavan R, Blomquist I, Glastonbury C, Bollen AW, Scharnhorst D, Reed SL, Kuriyama S, Visvesvara GS, Glaser CA. 2009. Under the Radar: Balamuthia Amebic Encephalitis. Clin Infect Dis 48:879-887.

2. Visvesvara GS, Moura H, Schuster FL. 2007. Pathogenic and opportunistic freeliving amoebae: Acanthamoeba spp., Balamuthia mandrillaris, Naegleria fowleri, and Sappinia diploidea. FEMS Immunol Med Microbiol 50:1-26.

3. Visvesvara GS. 2011. Pathogenic and Opportunistic Free-Living AmebaeManual of Clinical Microbiology, 10th Edition. American Society of Microbiology.

4. Bravo FG, Alvarez PJ, Gotuzzo E. 2011. Balamuthia mandrillaris infection of the skin and central nervous system: an emerging disease of concern to many specialties in medicine. Curr Opin Infect Dis 24:112-117.

5. Lehmer LM, Ulibarri GE, Ragsdale BD, Kunkle J. 2017. Cutaneous Balamuthia mandrillaris infection as a precursor to Balamuthia amoebic encephalitis (BAE) in a healthy 84-year-old Californian. Dermatol Online J 23.

6. Chang OH, Liu F, Knopp E, Muehlenbachs A, Cope JR, Ali I, Thompson R, George E. 2016. Centrofacial Balamuthiasis: case report of a rare cutaneous amebic infection. J Cutan Pathol 43:892-897. 
7. Bodi I, Dutt N, Hampton T, Akbar N. 2008. Fatal granulomatous amoebic meningoencephalitis due to Balamuthia mandrillaris. Pathol Res Pract 204:925-928.

8. Wilson MR, Shanbhag NM, Reid MJ, Singhal NS, Gelfand JM, Sample HA, Benkli B, O’Donovan BD, Ali IKM, Keating MK, Dunnebacke TH, Wood MD, Bollen A, DeRisi JL. 2015. Diagnosing Balamuthia mandrillaris Encephalitis With Metagenomic Deep Sequencing. Ann Neurol 78:722-730.

9. da Rocha-Azevedo B, Tanowitz HB, Marciano-Cabral F. 2009. Diagnosis of Infections Caused by Pathogenic Free-Living Amoebae. Interdiscip Perspect Infect Dis 2009:251406.

10. Cabello-Vílchez AM, Reyes-Batlle M, Montalbán-Sandoval E, Martín-Navarro CM, López-Arencibia A, Elias-Letts R, Guerra H, Gotuzzo E, Martínez-Carretero E, Piñero JE, Maciver SK, Valladares B, Lorenzo-Morales J. 2014. The isolation of Balamuthia mandrillaris from environmental sources from Peru. Parasitol Res 113:2509-2513.

11. Dunnebacke TH, Schuster FL, Yagi S, Booton GC. 2004. Balamuthia mandrillaris from soil samples. Microbiology 150:2837-2842.

12. Lares-Jiménez LF, Booton GC, Lares-Villa F, Velázquez-Contreras CA, Fuerst PA. 2014. Genetic analysis among environmental strains of Balamuthia mandrillaris recovered from an artificial lagoon and from soil in Sonora, Mexico. SI FLAM2013 145:S57-S61. 
13. LATIFI AR, NIYYATI M, LORENZO-MORALES J, HAGHIGHI A, SEYYED TABAEI SJ, LASJERDI Z. 2016. Presence of Balamuthia mandrillaris in hot springs from Mazandaran province, northern Iran. Epidemiol Infect 144:2456-2461.

14. Niyyati M, Lorenzo-Morales J, Rezaeian M, Martin-Navarro CM, Haghi AM, Maciver SK, Valladares B. 2009. Isolation of Balamuthia mandrillaris from urban dust, free of known infectious involvement. Parasitol Res 106:279-281.

15. Schuster FL, Dunnebacke TH, Booton GC, Yagi S, Kohlmeier CK, Glaser C, Vugia D, Bakardjiev A, Azimi P, Maddux-Gonzalez M, Martinez AJ, Visvesvara GS. 2003. Environmental Isolation of Balamuthia mandrillaris Associated with a Case of Amebic Encephalitis. J Clin Microbiol 41:3175-3180.

16. Saburi E, Rajaii T, Behdari A, Kohansal MH, Vazini H. 2017. Free-living amoebae in the water resources of Iran: a systematic review. J Parasit Dis Off Organ Indian Soc Parasitol 41:919-928.

17. Taravaud A, Ali M, Lafosse B, Nicolas V, Féliers C, Thibert S, Lévi Y, Loiseau PM, Pomel S. 2018. Enrichment of free-living amoebae in biofilms developed at upper water levels in drinking water storage towers: An inter- and intraseasonal study. Sci Total Environ 633:157-166.

18. Baquero RA, Reyes-Batlle M, Nicola GG, Martín-Navarro CM, López-Arencibia A, Guillermo Esteban J, Valladares B, Martínez-Carretero E, Piñero JE, LorenzoMorales J. 2014. Presence of potentially pathogenic free-living amoebae strains from well water samples in Guinea-Bissau. Pathog Glob Health 108:206-211. 
19. Schafer KR, Shah N, Almira-Suarez MI, Reese JM, Hoke GM, Mandell JW, Roy SL, Visvesvara G. 2015. Disseminated Balamuthia mandrillaris Infection. J Clin Microbiol 53:3072-3076.

20. van der Beek NAME, van Tienen C, de Haan JE, Roelfsema J, Wismans PJ, van Genderen PJJ, Tanghe HL, Verdijk RM, Titulaer MJ, van Hellemond JJ. 2015. Fatal Balamuthia mandrillaris Meningoencephalitis in the Netherlands after Travel to The Gambia. Emerg Infect Dis 21:896-898.

21. Shirabe T, Monobe Y, Visvesvara GS. 2002. An autopsy case of amebic meningoencephalitis. The first Japanese case caused by Balamuthia mandrillaris. Neuropathol Off J Jpn Soc Neuropathol 22:213-217.

22. Sangruchi T, Martinez AJ, Visvesvara GS. 1994. Spontaneous granulomatous amebic encephalitis: report of four cases from Thailand. Southeast Asian J Trop Med Public Health 25:309-313.

23. Tavares M, Correia da Costa JM, Carpenter SS, Santos LA, Afonso C, Aguiar A, Pereira J, Cardoso AI, Schuster FL, Yagi S, Sriram R, Visvesvara GS. 2006. Diagnosis of first case of Balamuthia amoebic encephalitis in Portugal by immunofluorescence and PCR. J Clin Microbiol 44:2660-2663.

24. Kodet R, Nohýnková E, Tichý M, Soukup J, Visvesvara GS. 1998. Amebic encephalitis caused by Balamuthia mandrillaris in a Czech child: description of the first case from Europe. Pathol Res Pract 194:423-429. 
25. Deol I, Robledo L, Meza A, Visvesvara GS, Andrews RJ. 2000. Encephalitis due to a free-living amoeba (Balamuthia mandrillaris): case report with literature review. Surg Neurol 53:611-616.

26. Riestra-Castaneda JM, Riestra-Castaneda R, Gonzalez-Garrido AA, Moreno PP, Martinez AJ, Visvesvara GS, Careaga FJ, Alba JLO de, Cornejo SG. 1997. Granulomatous Amebic Encephalitis Due to Balamuthia mandrillaris (Leptomyxiidae): Report of Four Cases from Mexico. Am J Trop Med Hyg 56:603-607.

27. Galarza M, Cuccia V, Sosa FP, Monges JA. 2002. Pediatric granulomatous cerebral amebiasis: a delayed diagnosis. Pediatr Neurol 26:153-156.

28. Hill CP, Damodaran O, Walsh P, Jevon GP, Blyth CC. 2011. Balamuthia amebic meningoencephalitis and mycotic aneurysms in an infant. Pediatr Neurol 45:45-48.

29. Moriarty P, Burke C, McCrossin D, Campbell R, Cherian S, Shahab MS, Visvesvara GS, Nourse C. 2014. Balamuthia mandrillaris Encephalitis: Survival of a Child With Severe Meningoencephalitis and Review of the Literature. J Pediatr Infect Dis Soc 3:e4-9.

30. Krasaelap A, Prechawit S, Chansaenroj J, Punyahotra P, Puthanakit T, Chomtho K, Shuangshoti S, Amornfa J, Poovorawan Y. 2013. Fatal Balamuthia Amebic Encephalitis in a Healthy Child: A Case Report with Review of Survival Cases. Korean J Parasitol 51:335-341. 
31. Bravo FG, Seas C. 2012. Balamuthia Mandrillaris Amoebic Encephalitis: An Emerging Parasitic Infection. Curr Infect Dis Rep 14:391-396.

32. Diaz JH. 2011. The public health threat from Balamuthia mandrillaris in the southern United States. J La State Med Soc Off Organ La State Med Soc 163:197204.

33. Centers for Disease Control and Prevention (CDC). 2008. Balamuthia amebic encephalitis--California, 1999-2007. MMWR Morb Mortal Wkly Rep 57:768771.

34. Khurana S, Hallur V, Goyal MK, Sehgal R, Radotra BD. 2015. Emergence of Balamuthia mandrillaris meningoencephalitis in India. Indian J Med Microbiol $33: 298-300$.

35. Cabello-Vílchez AM, Rodríguez-Zaragoza S, Piñero J, Valladares B, LorenzoMorales J. 2014. Balamuthia mandrillaris in South America: an emerging potential hidden pathogen in Perú. Exp Parasitol 145 Suppl:S10-19.

36. Martinez AJ, Visvesvara GS. 1997. Free-living, Amphizoic and Opportunistic Amebas. Brain Pathol 7:583-598.

37. Farnon EC, Kokko KE, Budge PJ, Mbaeyi C, Lutterloh EC, Qvarnstrom Y, da Silva AJ, Shieh W-J, Roy SL, Paddock CD, Sriram R, Zaki SR, Visvesvara GS, Kuehnert MJ, Weiss J, Komatsu K, Manch R, Ramos A, Echeverria L, Moore A, Zakowski P, Kittleson M, Kobashigawa J, Yoder J, Beach M, Mahle W, Kanter K, Geraghty P, 
Navarro E, Hahn C, Fujita S, Stinson J, Trachtenberg J, Byers P, Cheung M, Jie T,

Kaplan B, Gruessner R, Bracamonte E, Viscusi C, Gonzalez-Peralta R, Lawrence

R, Fratkin J, Butt F. 2016. Transmission of Balamuthia mandrillaris by Organ

Transplantation. Clin Infect Dis 63:878-888.

38. Gupte AA, Hocevar SN, Lea AS, Kulkarni RD, Schain DC, Casey MJ, Zendejas-Ruiz IR, Chung WK, Mbaeyi C, Roy SL, Visvesvara GS, da Silva AJ, Tallaj J, Eckhoff D, Baddley JW. 2014. Transmission of Balamuthia mandrillaris through Solid Organ Transplantation: Utility of Organ Recipient Serology to Guide Clinical Management. Am J Transplant Off J Am Soc Transplant Am Soc Transpl Surg 14:1417-1424.

39. Gelman BB, Rauf SJ, Nader R, Popov V, Borkowski J, Chaljub G, Nauta HW, Visvesvara GS. 2001. Amoebic Encephalitis Due to Sappinia diploidea. JAMA 285:2450-2451.

40. Adl SM, Simpson AGB, Farmer MA, Andersen RA, Anderson OR, Barta JR, Bowser SS, Brugerolle G, Fensome RA, Fredericq S, James TY, Karpov S, Kugrens P, Krug J, Lane CE, Lewis LA, Lodge J, Lynn DH, Mann DG, McCourt RM, Mendoza L, Moestrup O, Mozley-Standridge SE, Nerad TA, Shearer CA, Smirnov AV, Spiegel FW, Taylor MFJR. 2005. The new higher level classification of eukaryotes with emphasis on the taxonomy of protists. J Eukaryot Microbiol $52: 399-451$. 
41. Ahmad AF, Heaselgrave W, Andrew PW, Kilvington S. 2013. The In Vitro Efficacy of Antimicrobial Agents Against the Pathogenic Free-Living Amoeba Balamuthia mandrillaris. J Eukaryot Microbiol 60:539-543.

42. Turner NA, Russell AD, Furr JR, Lloyd D. 2000. Emergence of resistance to biocides during differentiation of Acanthamoeba castellanii. J Antimicrob Chemother 46:27-34.

43. Varga JH, Wolf TC, Jensen HG, Parmley VC, Rowsey JJ. 1993. Combined treatment of Acanthamoeba keratitis with propamidine, neomycin, and polyhexamethylene biguanide. Am J Ophthalmol 115:466-470.

44. Siddiqui R, Khan NA. 2015. Balamuthia mandrillaris: Morphology, biology, and virulence. Trop Parasitol 5:15-22.

45. Schuster FL, Visvesvara GS. 1996. Axenic growth and drug sensitivity studies of Balamuthia mandrillaris, an agent of amebic meningoencephalitis in humans and other animals. J Clin Microbiol 34:385-388.

46. González-Robles A, Lares-Villa F, Lares-Jiménez LF, Omaña-Molina M, SalazarVillatoro L, Martínez-Palomo A. 2015. Balamuthia mandrillaris: Further morphological observations of trophozoites by light, scanning and transmission electron microscopy. Exp Parasitol 157:150-155.

47. Siddiqui R, Ortega-Rivas A, Khan NA. 2008. Balamuthia mandrillaris resistance to hostile conditions. J Med Microbiol 57:428-431. 
48. Aksozek A, McClellan K, Howard K, Niederkorn JY, Alizadeh H. 2002. Resistance of Acanthamoeba castellanii cysts to physical, chemical, and radiological conditions. J Parasitol 88:621-623.

49. Fouque E, Trouilhé M-C, Thomas V, Hartemann P, Rodier M-H, Héchard Y. 2012. Cellular, Biochemical, and Molecular Changes during Encystment of Free-Living Amoebae. Eukaryot Cell 11:382-387.

50. SCHUSTER FL, GUGLIELMO BJ, VISVESVARA GS. 2006. In-Vitro Activity of Miltefosine and Voriconazole on Clinical Isolates of Free-Living Amebas: Balamuthia mandrillaris, Acanthamoeba spp., and Naegleria fowleri. J Eukaryot Microbiol 53:121-126.

51. Perez MT, Bush LM. 2007. Fatal amebic encephalitis caused by Balamuthia mandrillaris in an immunocompetent host: a clinicopathological review of pathogenic free-living amebae in human hosts. Ann Diagn Pathol 11:440-447.

52. 2017. Treatment | Balamuthia | Parasites | CDC.

53. Deetz TR, Sawyer MH, Billman G, Schuster FL, Visvesvara GS. 2003. Successful Treatment of Balamuthia Amoebic Encephalitis: Presentation of 2 Cases. Clin Infect Dis 37:1304-1312.

54. Vollmer ME, Glaser C. 2016. A Balamuthia survivor. JMM Case Rep 3:e005031. 
55. Jung S, Schelper RL, Visvesvara GS, Chang HT. 2004. Balamuthia mandrillaris meningoencephalitis in an immunocompetent patient: an unusual clinical course and a favorable outcome. Arch Pathol Lab Med 128:466-468.

56. Roy SL, Atkins JT, Gennuso R, Kofos D, Sriram RR, Dorlo TP, Hayes T, Qvarnstrom Y, Kucerova Z, Guglielmo BJ, Visvesvara GS. 2015. Assessment of blood-brain barrier penetration of miltefosine used to treat a fatal case of granulomatous amebic encephalitis possibly caused by an unusual Balamuthia mandrillaris strain. Parasitol Res 114:4431-4439.

57. Martínez DY, Seas C, Bravo F, Legua P, Ramos C, Cabello AM, Gotuzzo E. 2010. Successful Treatment of Balamuthia mandrillaris Amoebic Infection with Extensive Neurological and Cutaneous Involvement. Clin Infect Dis 51:e7-e11.

58. Doyle JS, Campbell E, Fuller A, Spelman DW, Cameron R, Malham G, Gin D, Lewin SR. 2011. Balamuthia mandrillaris brain abscess successfully treated with complete surgical excision and prolonged combination antimicrobial therapy. J Neurosurg 114:458-462.

59. Prasad K, Bhatia R, Srivastava MVP, Pardasani V, Garg A, Rishi A. 2008. Fatal subacute necrotising brainstem encephalitis in a young man due to a rare parasitic (Balamuthia) infection. Pract Neurol 8:112-117.

60. Pritzker AS, Kim BK, Agrawal D, Southern PM, Pandya AG. 2004. Fatal granulomatous amebic encephalitis caused by Balamuthia mandrillaris presenting as a skin lesion. J Am Acad Dermatol 50:S38-41. 
61. Bakardjiev A, Azimi PH, Ashouri N, Ascher DP, Janner D, Schuster FL, Visvesvara GS, Glaser C. 2003. Amebic encephalitis caused by Balamuthia mandrillaris: report of four cases. Pediatr Infect Dis J 22:447-453.

62. Bergogne-Berezin E, Berthelot G, Muller-Serieys C. 1987. [Present status of nitroxoline]. Pathol Biol (Paris) 35:873-878.

63. Mrhar A, Kopitar Z, Kozjek F, Presl V, Karba R. 1979. Clinical pharmacokinetics of nitroxoline. Int J Clin Pharmacol Biopharm 17:476-481.

64. Sorel RH, Snelleman C, Hulshoff A. 1981. High-performance liquid chromatographic analysis of nitroxoline in plasma and urine. J Chromatogr 222:241-248.

65. Lares-Jiménez LF, Gámez-Gutiérrez RA, Lares-Villa F. 2015. Novel culture medium for the axenic growth of Balamuthia mandrillaris. Diagn Microbiol Infect Dis 82:286-288.

66. Siddiqui R, Jarroll EL, Khan NA. 2010. Balamuthia mandrillaris: Role of galactose in encystment and identification of potential inhibitory targets. Biol Pathog Free-Living Amoebae - Compil XIIIth Int Meet Biol Pathog Free-Living Amoebae FLAM 2009 Tenerife Spain 126:22-27.

67. Brideau C, Gunter B, Pikounis B, Liaw A. 2003. Improved statistical methods for hit selection in high-throughput screening. J Biomol Screen 8:634-647. 
68. Sobke A, Klinger M, Hermann B, Sachse S, Nietzsche S, Makarewicz O, Keller PM, Pfister W, Straube E. 2012. The Urinary Antibiotic 5-Nitro-8-Hydroxyquinoline (Nitroxoline) Reduces the Formation and Induces the Dispersal of Pseudomonas aeruginosa Biofilms by Chelation of Iron and Zinc. Antimicrob Agents Chemother 56:6021-6025.

69. Prachayasittikul V, Prachayasittikul S, Ruchirawat S, Prachayasittikul V. 2013. 8-Hydroxyquinolines: a review of their metal chelating properties and medicinal applications. Drug Des Devel Ther 7:1157-1178.

70. Lee X, Reimmann C, Greub G, Sufrin J, Croxatto A. 2012. The Pseudomonas aeruginosa toxin L-2-amino-4-methoxy-trans-3-butenoic acid inhibits growth and induces encystment in Acanthamoeba castellanii. Microbes Infect 14:268272.

71. Bando Y, Takahashi T, Uehara H, Kagegi T, Nagahiro S, Izumi K. 2012. Autopsy case of amebic granulomatous meningoencephalitis caused by Balamuthia mandrillaris in Japan. Pathol Int 62:418-423.

72. Naber KG, Niggemann H, Stein G, Stein G. 2014. Review of the literature and individual patients' data meta-analysis on efficacy and tolerance of nitroxoline in the treatment of uncomplicated urinary tract infections. BMC Infect Dis 14.

73. Lazovic J, Guo L, Nakashima J, Mirsadraei L, Yong W, Kim HJ, Ellingson B, Wu H, Pope WB. 2015. Nitroxoline induces apoptosis and slows glioma growth in vivo. Neuro-Oncol 17:53-62. 
bioRxiv preprint doi: https://doi.org/10.1101/331785; this version posted June 6, 2018. The copyright holder for this preprint (which was not certified by peer review) is the author/funder, who has granted bioRxiv a license to display the preprint in perpetuity. It is made available under aCC-BY-NC-ND 4.0 International license.

Laurie and White et al., Inhibition of Balamuthia mandrillaris by nitroxoline

74. Seidel JS, Harmatz P, Visvesvara GS, Cohen A, Edwards J, Turner J. 1982.

Successful Treatment of Primary Amebic Meningoencephalitis. N Engl J Med

306:346-348. 


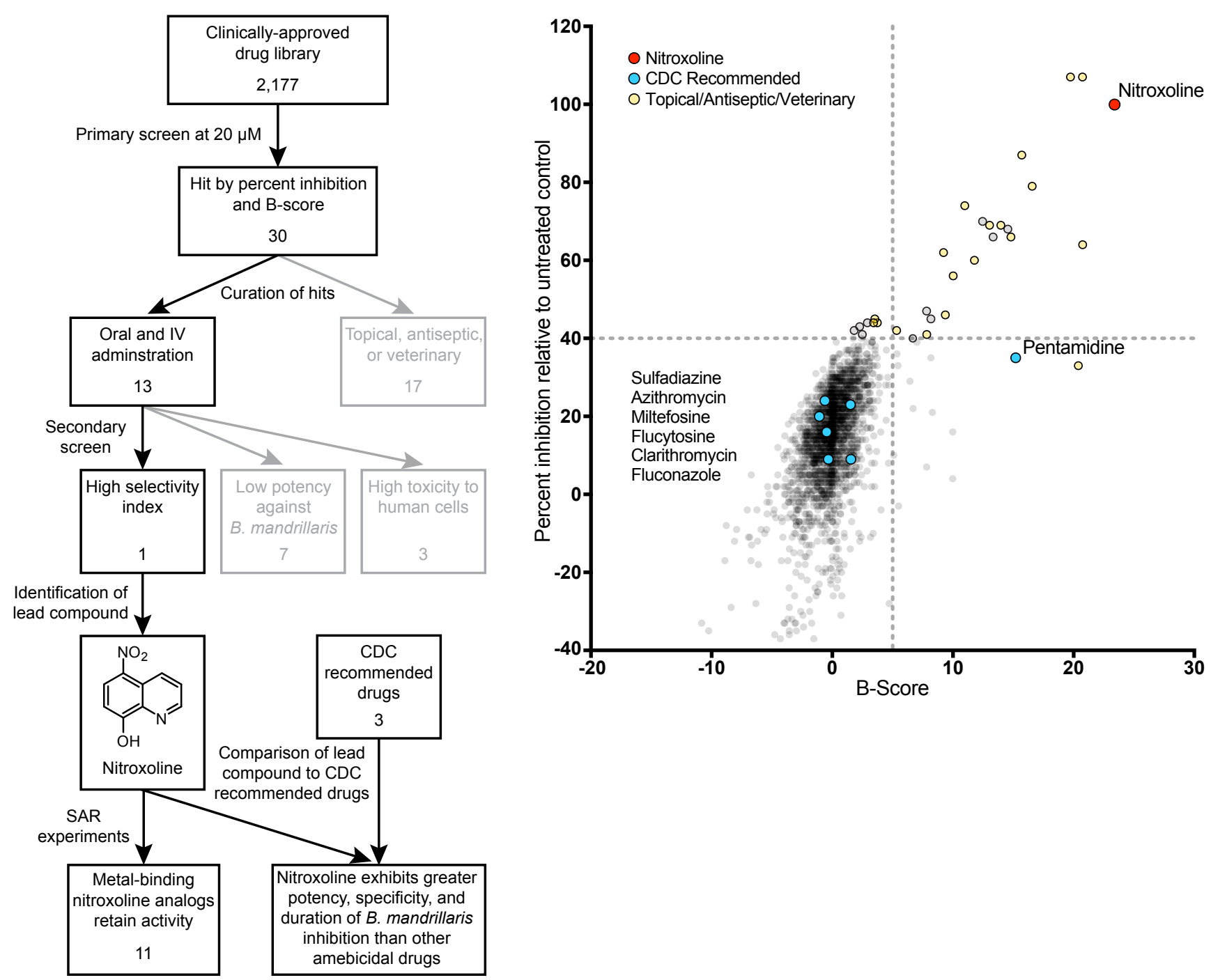

Figure 1. (A) Workflow for high-throughput screening of clinically-approved compounds for in vitro activity against $B$. mandrillaris. A primary screen of 2,177 clinically-approved compounds yielded 30 hits meeting the percent inhibition and B-score criteria, of which only 13 candidates were available for oral or IV administration (Fig. 1B). Secondary screening identified only one novel lead compound, nitroxoline, which displayed high selectivity for inhibition of $B$. mandrillaris viability (Table S1C). Structure-activity relationship (SAR) experiments show that 11 of 12 nitroxoline analogs tested with potential metal binding domains remain active against $B$. mandrillaris, suggesting that metal binding plays a role in the mechanism of inhibition by nitroxoline (Fig. 2). Comparison of nitroxoline to three drugs recommended by the $\mathrm{CDC}$ for treatment of $B$. mandrillaris CNS infections (pentamidine isethionate, miltefosine, and azithromycin) indicates that nitroxoline is the most potent and specific inhibitor of $B$. mandrillaris of the compounds tested (Fig. 3, 4 and Table 1). (B) Plot of percent inhibition relative to untreated controls and B-score measured for each compound in a library of 2,177 clinically-approved compounds. Raw data used to calculate these values is compiled in Table S1A. Drugs recommended by the CDC for treatment of GAE are highlighted in blue. Drugs that are classified as antiseptic, topical, and/or have not been used in humans are shown in yellow. The quinoline antibiotic nitroxoline, which was the top hit identified in this screen, is highlighted in red. 


\section{Figure 2}<smiles></smiles>

Nitroxoline [1]

$\mathrm{IC}_{50}=4.77 \mu \mathrm{M}$<smiles>[R]c1c([R])c(O)c2ncccc2c1[R]</smiles>

5,6,7-substituted

hydroxyquinolines [4-12]

$$
\begin{gathered}
\mathrm{R}_{1}=\mathrm{F}, \mathrm{Cl}, \mathrm{Br}, \mathrm{CH}_{3}, \mathrm{NH}_{2}, \mathrm{NO} ; \mathrm{R}_{2}=\mathrm{R}_{3}=\mathrm{H} \\
\mathrm{R}_{1}=\mathrm{R}_{3}=\mathrm{Cl}, \mathrm{NO}_{2} ; \mathrm{R}_{2}=\mathrm{H} \\
\mathrm{R}_{2}=\mathrm{NO}_{2} ; \mathrm{R}_{1}=\mathrm{R}_{3}=\mathrm{H} \\
\mathrm{IC}_{50}=16.80-60.41 \mu \mathrm{M}
\end{gathered}
$$<smiles>Oc1cccc2cccnc12</smiles>

8-Hydroxyquinoline [2]

$\mathrm{IC}_{50}=30.51 \mu \mathrm{M}$<smiles>O=S(=O)(O)c1ccc(O)c2ncccc12</smiles>

8-Hydroxy-5quinolinesulfonic acid [13]

$\mathrm{IC}_{50}=338 \mu \mathrm{M}$<smiles>O=[N+]([O-])c1cccc2ncccc12</smiles>

5-Nitroquinoline [3] $\mathrm{IC}_{50}=82.69 \mu \mathrm{M}$

1,10-phenanthroline [14] $\mathrm{IC}_{50}=15.89 \mu \mathrm{M}$

Figure 2. Structure-activity-relationship experiments suggest that nitroxoline inhibits $B$. mandrillaris through a mechanism related to metal binding. Structures and $\mathrm{IC}_{50}$ values are shown for nitroxoline and select analogs; additional compounds are shown in Table S2. Nitroxoline is made up of a quinoline core with a nitro group at the 5-position and hydroxyl group at the 8-position. Analogs lacking the 8-position hydroxyl group were generally inactive with IC50 values greater than $80 \mu \mathrm{M}$ (e.g. 5-Nitroquinoline [3]). Twelve nitroxoline analogs with predicted metal binding activity were tested and of these, 1,10-phenanthroline [14] and 10 out of 11 compounds with an 8-position hydroxyl group (e.g. 8-Hydroxyquinoline [2]) were active with $\mathrm{IC}_{50}$ values ranging from $17-60 \mu \mathrm{M}$. The only inactive analog with an 8-position hydroxyl group was 8-Hydroxy-5-quinolinesulfonic acid [13]. Variance of the 5-position nitro group reduced potency compared to nitroxoline, but no trend related to aromatic electronic effects is apparent. 


\section{Figure 3}

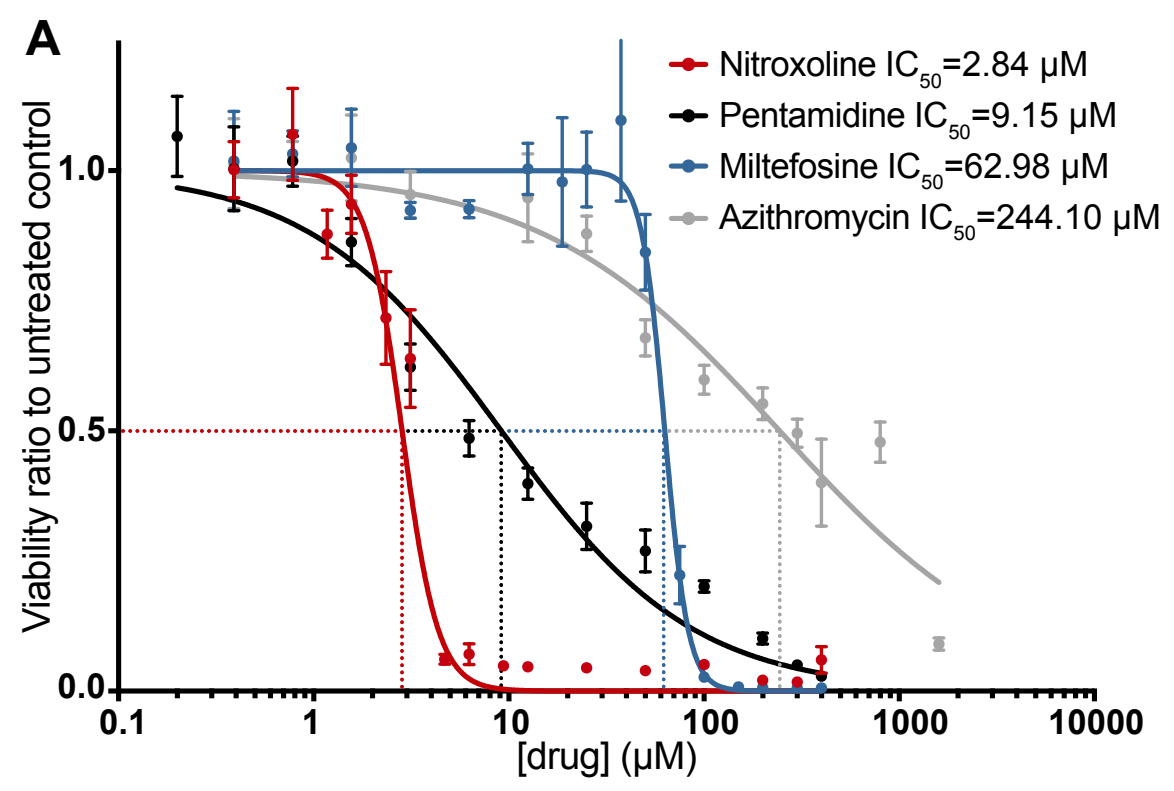

B

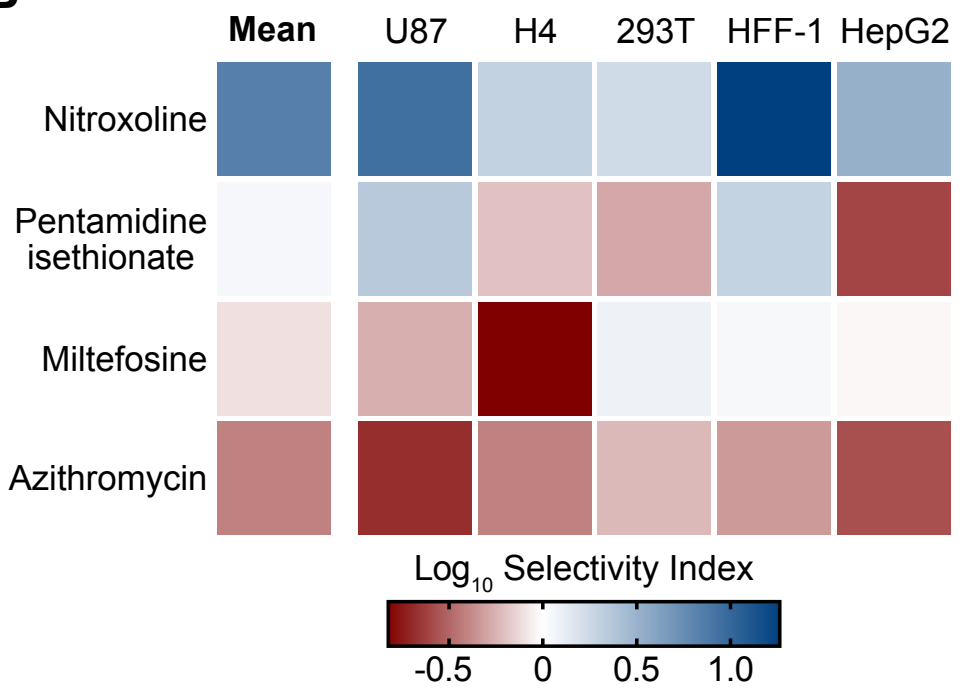

Figure 3. Potency and selectivity for inhibition of $B$. mandrillaris viability by nitroxoline, pentamidine isethionate, miltefosine, and azithromycin. (A) Dose-response curves show the effect of nitroxoline (red), pentamidine isethionate (black), miltefosine (blue), and azithromycin (grey) on the viability of $B$. mandrillaris trophozoite populations following 72 hours of treatment. Data points are means and standard errors of at least three independent biological replicates. Nitroxoline is the most potent inhibitor of $B$. mandrillaris viability with an $\mathrm{IC}_{50}$ of $2.84 \mu \mathrm{M}$. (B) Heat map showing the $\log _{10}$ selectivity index (human cell $\mathrm{CC}_{50} / B$. mandrillaris $\mathrm{IC}_{50}$ ) for nitroxoline, pentamidine, isethionate, miltefosine, and azithromycin calculated from the ratio of human cell $\mathrm{CC}_{50}$ to $B$. mandrillaris $\mathrm{IC}_{50}$. Nitroxoline exhibited the greatest mean $\log _{10}$ selectivity index at 0.832 and was the only drug with a positive $\log _{10}$ selectivity index comparing $B$. mandrillaris inhibition to all cell lines tested. 
Figure 4

A

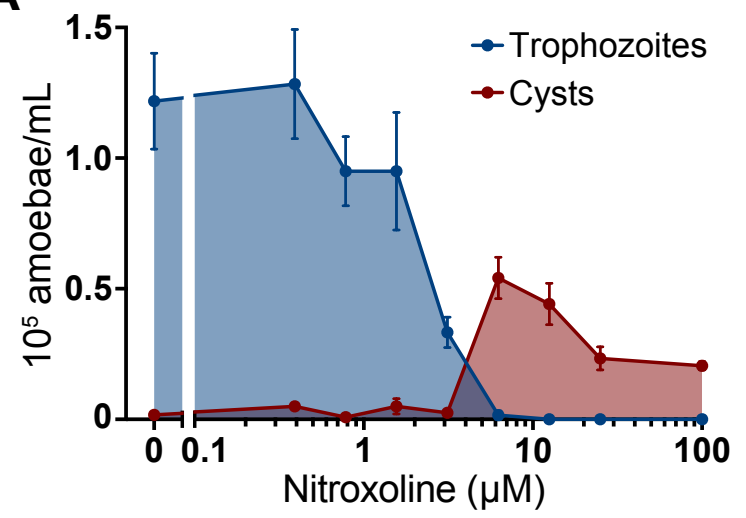

C

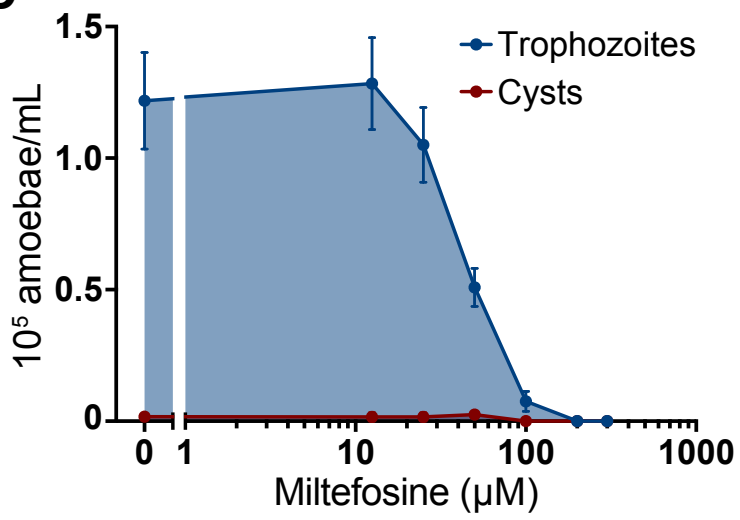

B

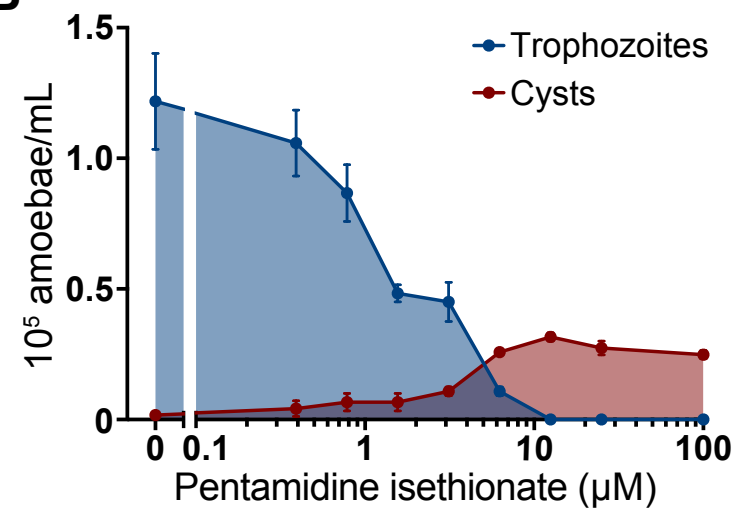

D

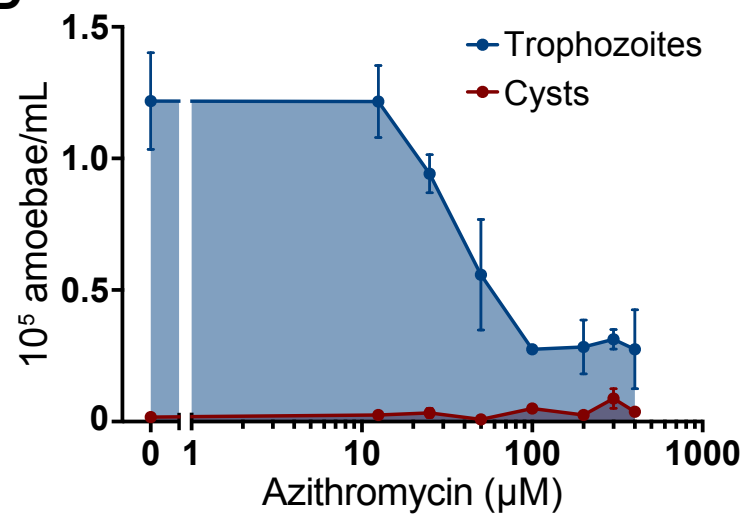

$\mathbf{E}$

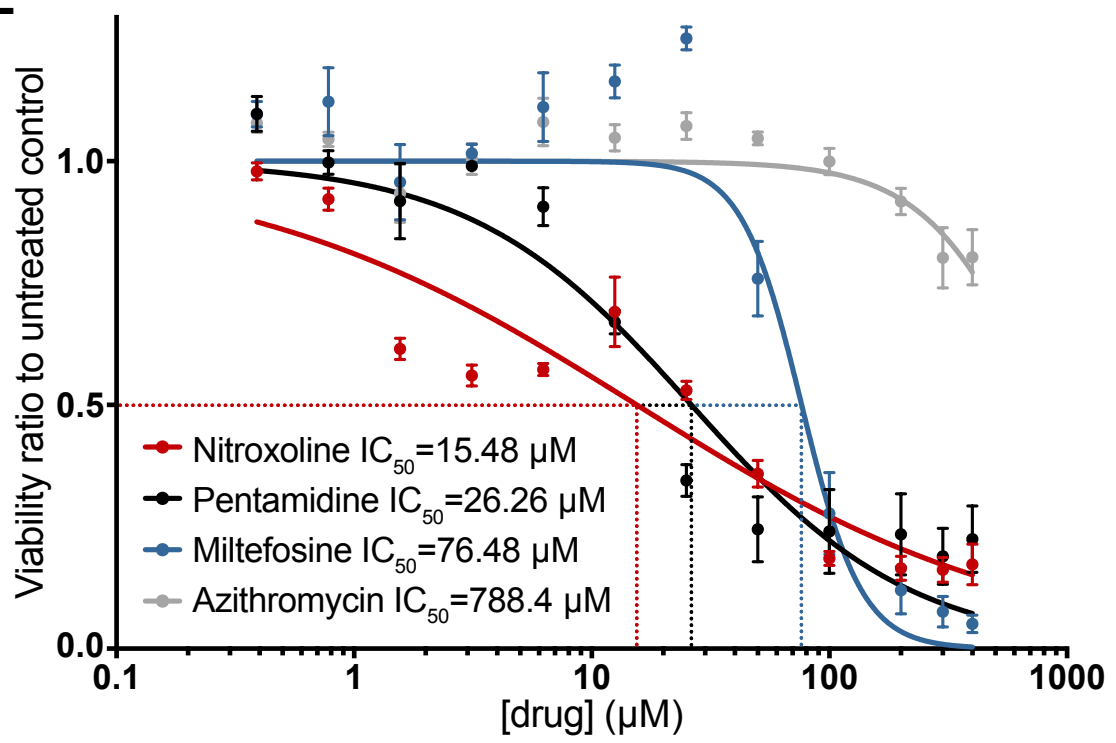

Figure 4. Relationship of drug treatment to $B$. mandrillaris encystment. (A-D) Changes in the number of trophozoites (blue) and cysts (red) in $B$. mandrillaris populations following 72 hours of treatment with various concentrations of nitroxoline $(A)$, pentamidine isethionate $(B)$, miltefosine (C), and azithromycin (D). Low micromolar doses of nitroxoline and pentamidine isethionate cause an increase in the total number of cysts observed in $B$. mandrillaris populations and an increase in the ratio of cysts to trophozoites. No increase in encystment is observed in B. mandrillaris populations treated with miltefosine or azithromycin. (E) Dose-response curve showing the effect of nitroxoline (red), pentamidine isethionate (black), miltefosine (blue), and azithromycin (grey) on the viability of pre-formed $B$. mandrillaris cysts. Nitroxoline is the most potent inhibitor of cysts with an $\mathrm{IC}_{50}$ of $15.48 \mu \mathrm{M}$. Compared to trophozoites (Fig. 2A), cysts are substantially less sensitive to all drugs except for miltefosine, which had a similar $\mathrm{IC}_{50}$ for inhibition of both $B$. mandrillaris forms. 


\section{Table 1}

Recrudescence time of active $B$. mandrillaris following drug treatment

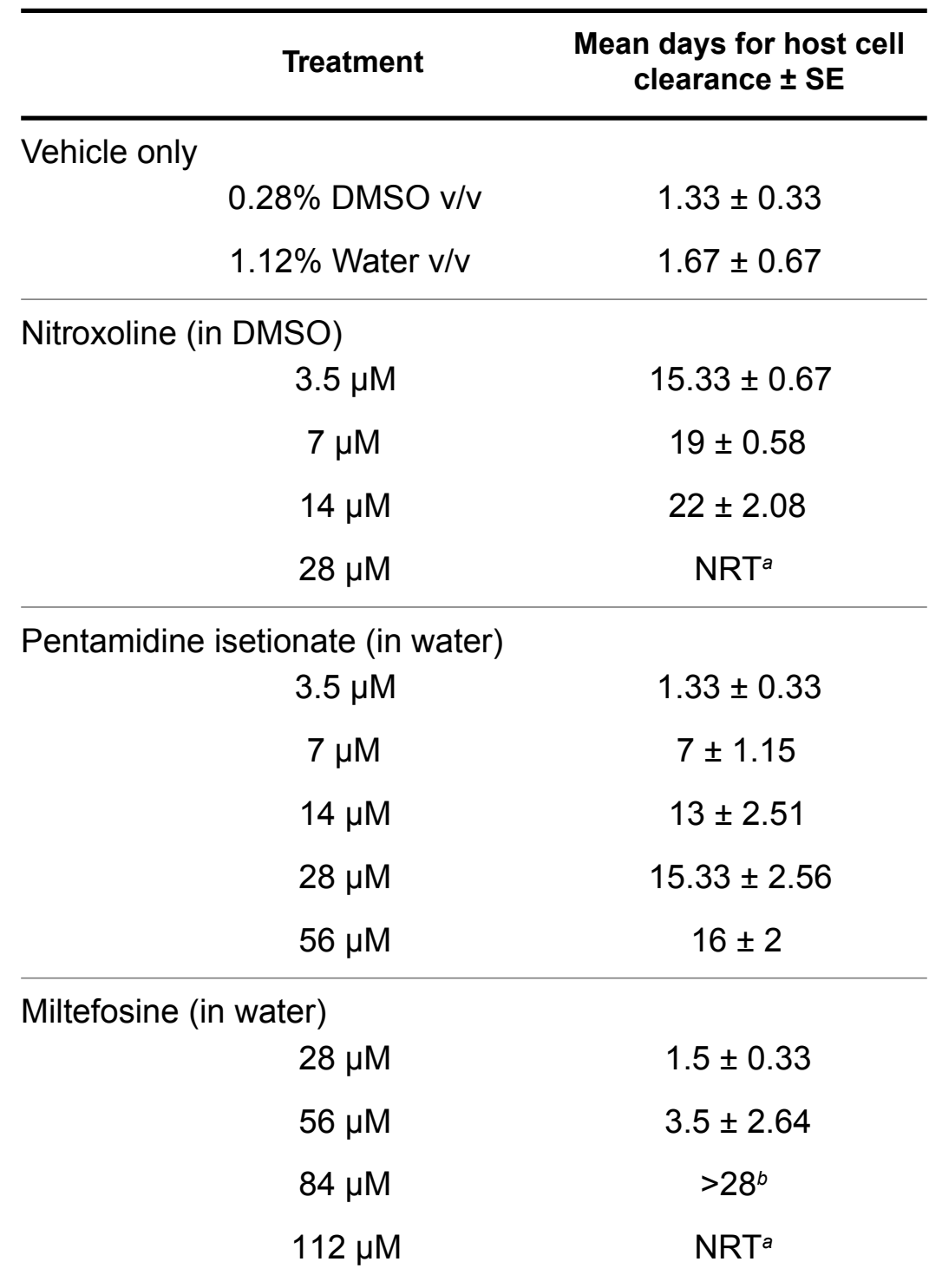

\footnotetext{
${ }^{a}$ No recovery of trophozoites or host cell destruction observed through 28 days

${ }^{b}$ Incomplete recovery of trophozoites and destruction of host cells on day 28
}

Table 1. Rate of recrudescence and host cell destruction by $B$. mandrillaris following drug treatment. Cultures of $B$. mandrillaris were exposed to the indicated drug concentrations for 72 hours, removed from drug, and transferred to monolayers of human cells where the time until complete monolayer clearance was measured. Mean host cell clearance time is reported as the average of three replicates \pm the standard error. Low micromolar doses of nitroxoline delay $B$. mandrillaris recrudescence by two to three weeks compared to untreated controls. Doses of $28 \mu \mathrm{M}$ nitroxoline and $112 \mu \mathrm{M}$ miltefosine completely prevented recovery of $B$. mandrillaris and damage to host cells throughout the 28-day duration of the experiment. 


\section{Figure 5}
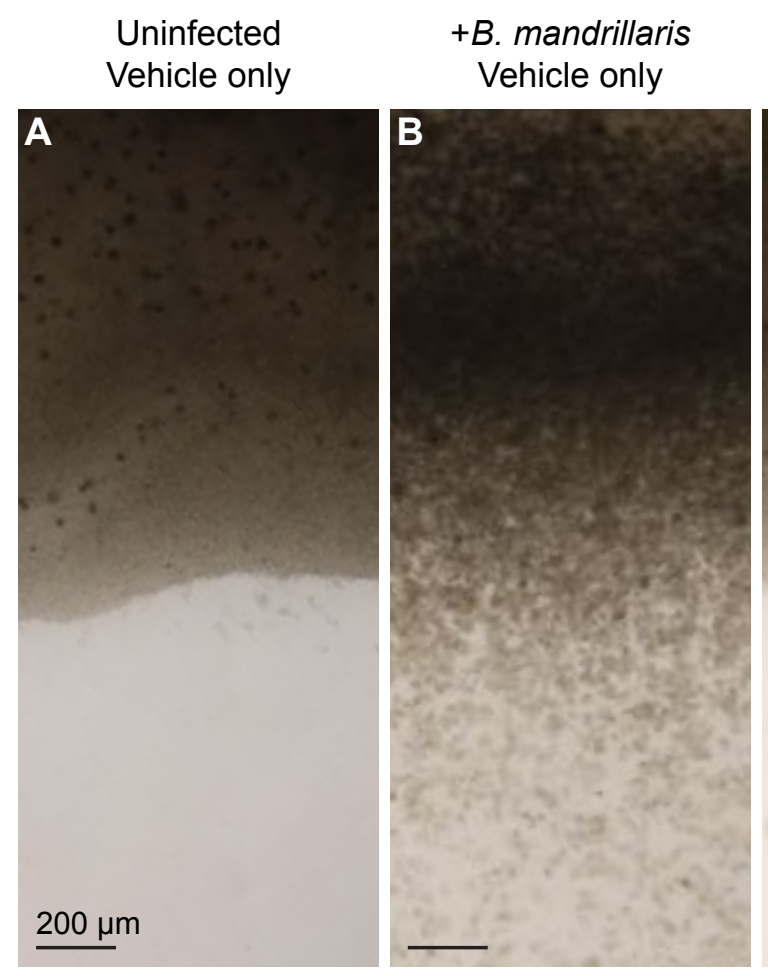

+ B. mandrillaris $+35 \mu \mathrm{M}$ nitroxoline

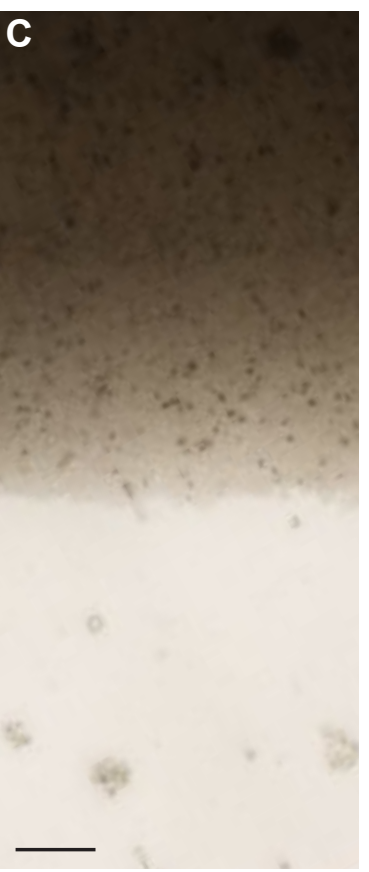

Figure 5. Nitroxoline prevents $B$. mandrillaris-mediated destruction of human brain tissue explants. Panels show brightfield images representative of two biological replicates 4 days after exposure to the indicated conditions. Media was changed at 20 hours post-infection to remove nitroxoline or vehicle. (A) Uninfected, untreated (vehicle only) tissues have distinct edges and maintain cell density throughout culture. (B) B. mandrillaris-infected, untreated (vehicle only) tissues show widespread damage, particularly at edges where loss of cell density and disorder of tissue structure is apparent. Large numbers of $B$. mandrillaris trophozoites are observed intermixed with human cells and outside of the tissue (lower half of image). (C) B. mandrillaris-infected tissues treated with $35 \mu \mathrm{M}$ nitroxoline simultaneously with inoculation do not show signs of tissue damage or loss of cell density and maintain distinct edges similar to uninfected tissues. Clusters of $B$. mandrillaris cysts are observed outside the boundaries of the tissue. Additonal images are shown in Figure S1. 
bioRxiv preprint doi: https://doi.org/10.1101/331785; this version posted June 6, 2018. The copyright holder for this preprint (which was not certified by peer review) is the author/funder, who has granted bioRxiv a license to display the preprint in perpetuity. It is made available under

Figure S1
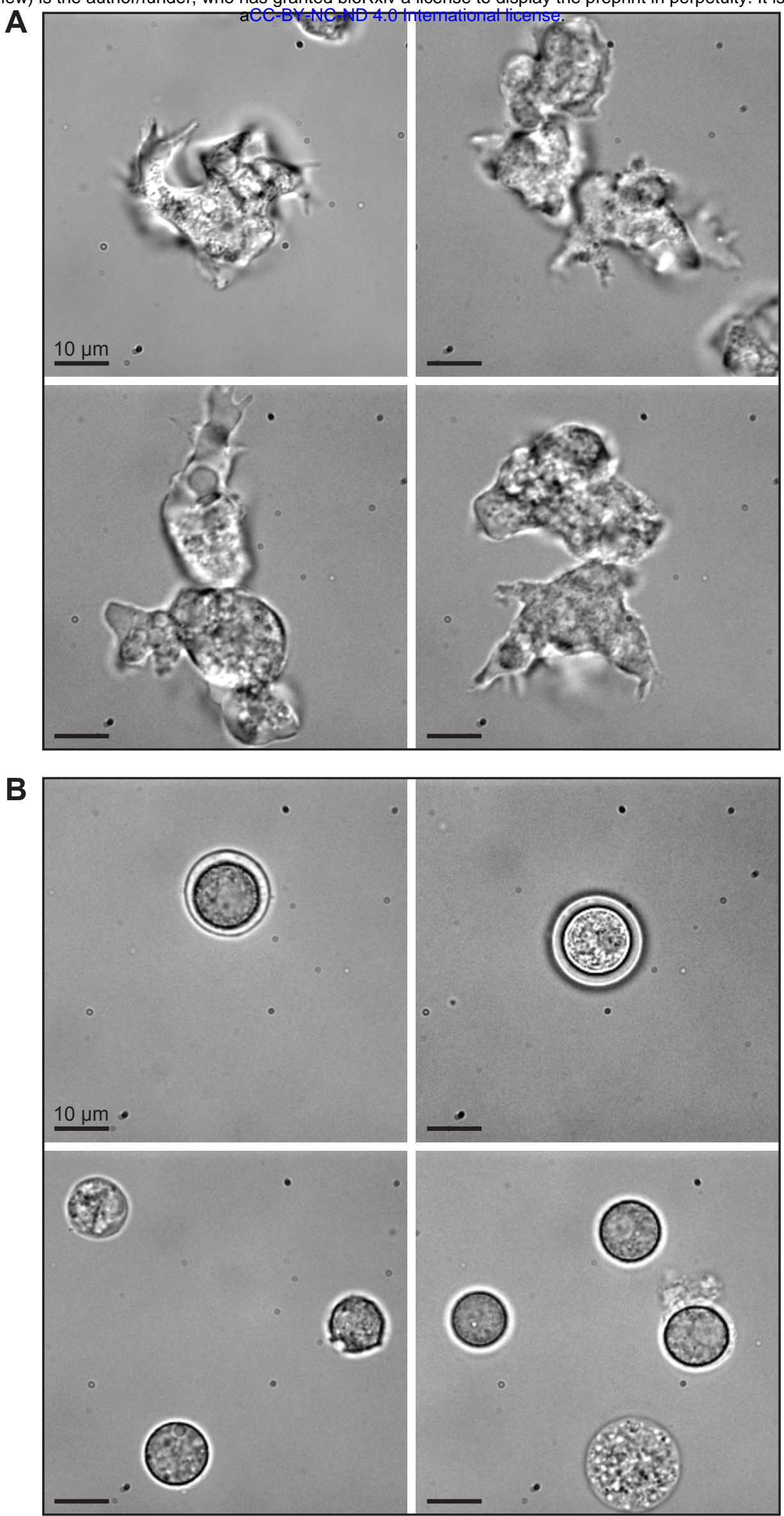

Figure S1. Example brightfield images of B. mandrillaris trophozoites and cysts. (A) Example images show $B$. mandrillaris trophozoites in log-phase growth. Trophozoites are pleomorphic and can be elongated or generally rounded, often with highly branched pseudopodia. (B) Example images show B. mandrillaris cysts induced by galactose exposure. Cysts are spherical, generally smaller in diameter than trophozoites, and can have visibly distinct layers. Some cysts show signs of vacuolization that may be indicative of cell death. 
bigRyjv preprint doi: https;//doiorg/10.1101/331785; this versign posted Jupe 6, 2018. The copyrightholder for this preprint (which was not by peer review) is

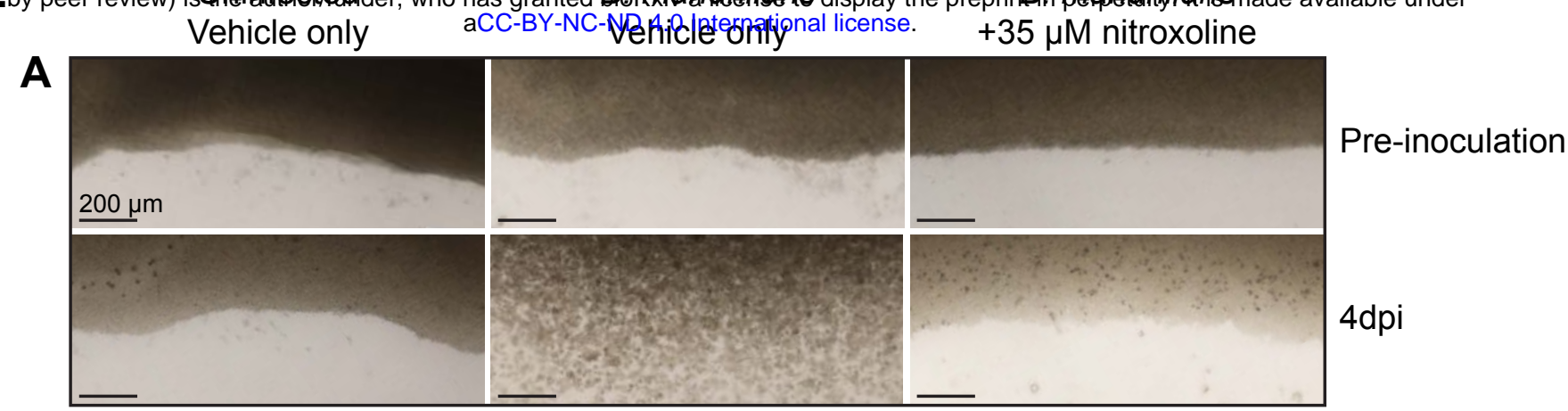

B

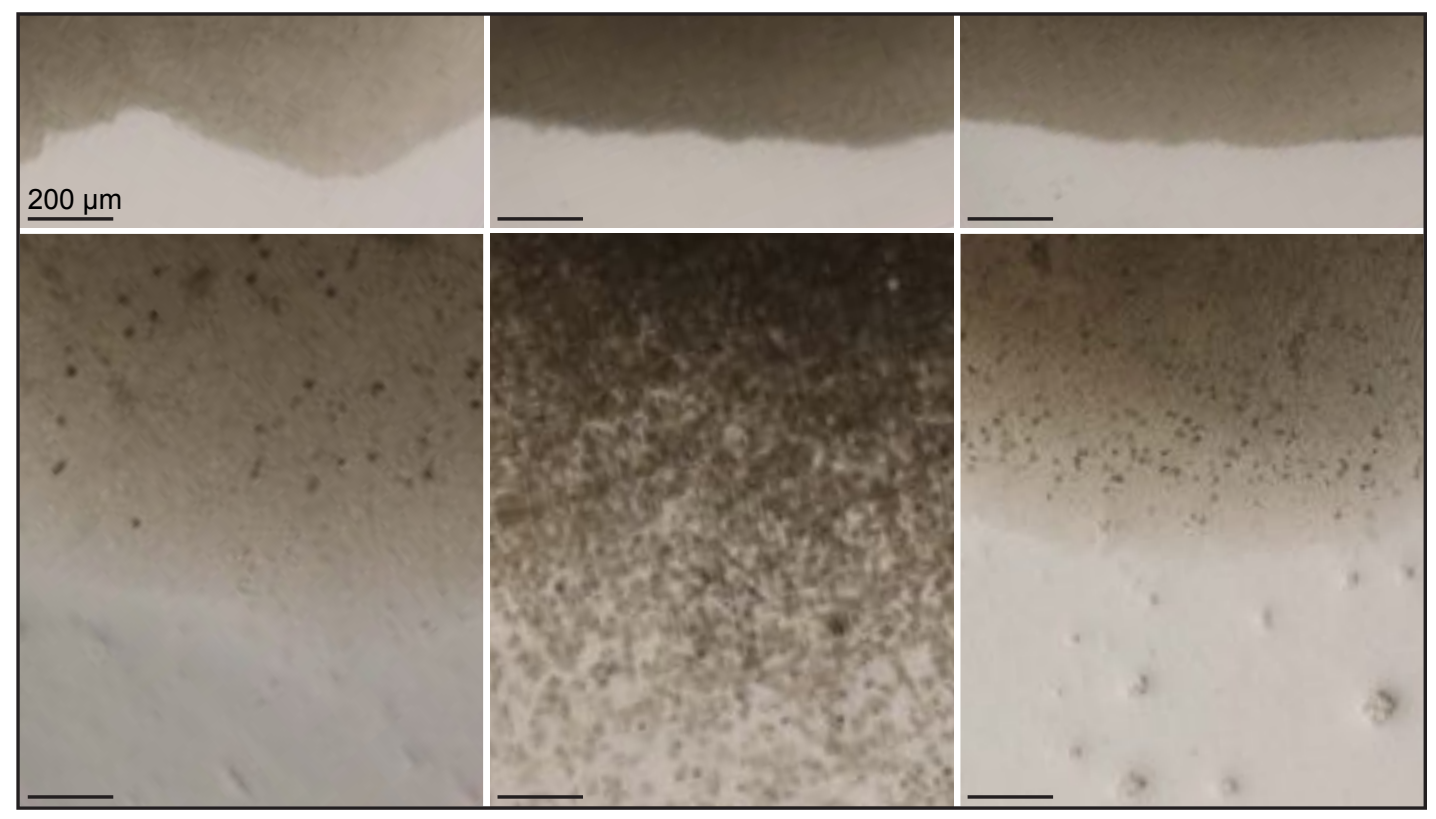

Pre-inoculation
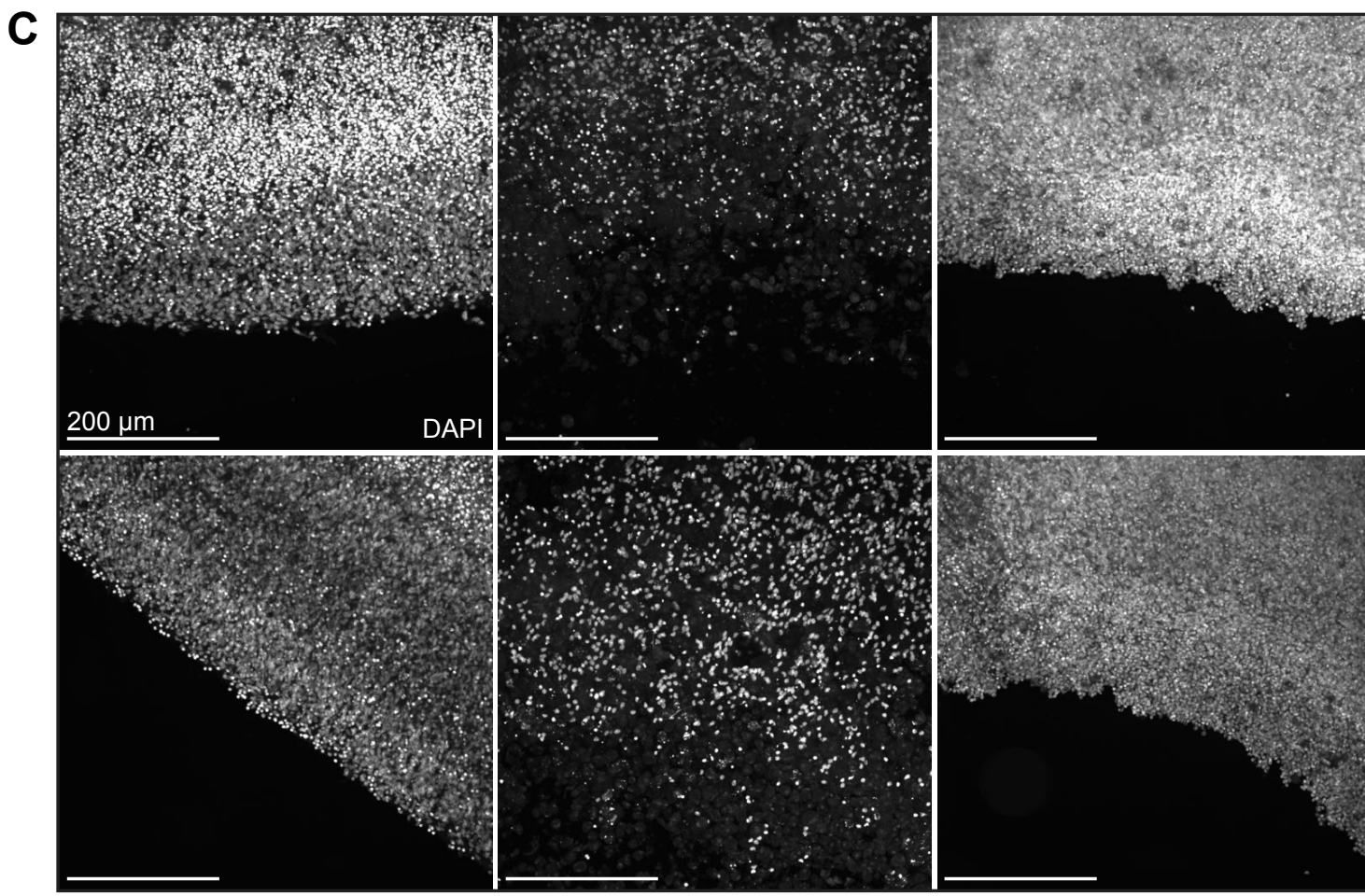

4dpi
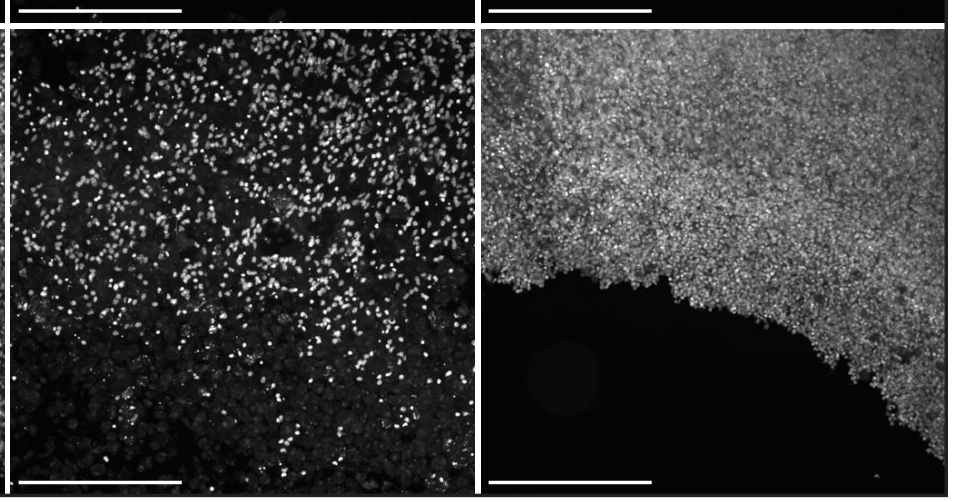

4dpi

Figure S2. (A and B) Brightfield images representative of two biological replicates for human brain tissue explants before and after exposure to the indicated conditions. Nitroxoline or vehicle was added simultaneously with $B$. mandrillaris trophozoites and removed after 20 hours. Four days after exposure to B. mandrillaris, untreated tissues show widespread damage and loss of cell density while nitroxoline treated tissues remain intact and appear similar to uninfected tissues. Large numbers of $B$. mandrillaris trophozoites can be seen at the edges of untreated tissues, while only clusters of cysts are observed in nitroxoline-treated tissues. (C) Images representative of two biological replicates of human brain tissue explants fixed and stained with DAPI four days after exposure to the indicated conditions (two images per condition). The number of host cell nuclei is dramatically reduced in untreated, $B$. mandrillaris-infected tissues compared to uninfected tissues, whereas $B$. mandrillaris-infected tissues treated with nitroxoline show no apparent loss of nuclei. 
Table S2

\begin{tabular}{|c|c|c|c|c|c|c|}
\hline Compound name & $\begin{array}{c}\text { Compound } \\
\text { number }\end{array}$ & Structure & $\mathrm{IC}_{50}(\mu \mathrm{M})$ & $\mathbf{R}^{2}$ & Hill slope & $\begin{array}{l}\text { Compound } \\
\text { source }\end{array}$ \\
\hline $\begin{array}{l}\text { 8-Hydroxy-5- } \\
\text { nitroquinoline }\end{array}$ & 1 & & 4.77 & 0.980 & 3.49 & $\begin{array}{l}\text { Selleck } \\
\text { Chemical }\end{array}$ \\
\hline 8-Hydroxyquinoline & 2 & & 30.51 & 0.929 & 1.27 & $\begin{array}{l}\text { Sigma- } \\
\text { Aldrich }\end{array}$ \\
\hline 5-Nitroquinoline & 3 & & 82.69 & 0.888 & 0.93 & $\begin{array}{l}\text { Sigma- } \\
\text { Aldrich }\end{array}$ \\
\hline $\begin{array}{l}\text { 5-Fluoroquinolin- } \\
8 \text {-ol }\end{array}$ & 4 & & 60.41 & 0.953 & 4.92 & MolPort \\
\hline $\begin{array}{l}\text { 5-Chloro-8- } \\
\text { quinolinol }\end{array}$ & 5 & & 28.69 & 0.968 & 16.11 & $\begin{array}{l}\text { Sigma- } \\
\text { Aldrich }\end{array}$ \\
\hline $\begin{array}{l}\text { 5-Bromo-8-hydroxy } \\
\text { quinoline }\end{array}$ & 6 & & 48.94 & 0.991 & 3.35 & $\begin{array}{c}\text { AK } \\
\text { Scientific }\end{array}$ \\
\hline $\begin{array}{l}\text { 5-Methylquinolin- } \\
\text { 8-ol }\end{array}$ & 7 & & 19.94 & 0.984 & 3.57 & $\begin{array}{c}\text { AK } \\
\text { Scientific }\end{array}$ \\
\hline $\begin{array}{l}\text { 5-Amino-8- } \\
\text { hydroxyquinoline } \\
\text { dihydrochloride }\end{array}$ & 8 & & 37.55 & 0.664 & 0.82 & $\begin{array}{l}\text { Sigma- } \\
\text { Aldrich }\end{array}$ \\
\hline $\begin{array}{l}\text { 5-Nitroso-8- } \\
\text { hydroxyquinoline }\end{array}$ & 9 & & 48.95 & 0.986 & 4.14 & $\begin{array}{c}\text { AK } \\
\text { Scientific }\end{array}$ \\
\hline $\begin{array}{l}\text { 5,7-Dichloro-8- } \\
\text { quinolinol }\end{array}$ & 10 & & 50.03 & 0.948 & 3.69 & $\begin{array}{l}\text { Sigma- } \\
\text { Aldrich }\end{array}$ \\
\hline
\end{tabular}


bioRxiv preprint doi: https://doi.org/10.1101/331785; this version posted June 6, 2018. The copyright holder for this preprint (which was not certified by peer review) is the author/funder, who has granted bioRxiv a license to display the preprint in perpetuity. It is made available under

Table S2 (continued)

\begin{tabular}{|c|c|c|c|c|c|c|}
\hline Compound name & $\begin{array}{c}\text { Compound } \\
\text { number }\end{array}$ & Structure & $\mathrm{IC}_{50}(\mu \mathrm{M})$ & $\mathbf{R}^{2}$ & Hill slope & $\begin{array}{c}\text { Compound } \\
\text { source }\end{array}$ \\
\hline $\begin{array}{l}\text { 5,7-Dinitro-8- } \\
\text { quinolinol }\end{array}$ & 11 & & 58.89 & 0.903 & 4.49 & $\begin{array}{l}\text { Sigma- } \\
\text { Aldrich }\end{array}$ \\
\hline $\begin{array}{l}\text { 8-Hydroxy-6- } \\
\text { nitroquinoline }\end{array}$ & 12 & & 16.80 & 0.894 & 3.82 & MolPort \\
\hline $\begin{array}{l}\text { 8-Hydroxy-5- } \\
\text { quinolinesulfonic } \\
\text { acid }\end{array}$ & 13 & & 338.3 & 0.769 & 1.21 & $\begin{array}{l}\text { Sigma- } \\
\text { Aldrich }\end{array}$ \\
\hline $\begin{array}{l}\text { 1,10- } \\
\text { Phenanthroline }\end{array}$ & 14 & & 15.89 & 0.967 & 3.71 & $\begin{array}{l}\text { Sigma- } \\
\text { Aldrich }\end{array}$ \\
\hline 6-Nitroquinolone & 15 & & 189.4 & 0.808 & 1.41 & $\begin{array}{l}\text { Sigma- } \\
\text { Aldrich }\end{array}$ \\
\hline $\begin{array}{l}\text { 8-Quinolinol N- } \\
\text { oxide }\end{array}$ & 16 & & 165.0 & 0.756 & 1.64 & $\begin{array}{l}\text { Sigma- } \\
\text { Aldrich }\end{array}$ \\
\hline $\begin{array}{l}\text { 8-Ethoxy-5- } \\
\text { nitroquinoline }\end{array}$ & 17 & & 434.2 & 0.709 & 1.37 & $\begin{array}{l}\text { Sigma- } \\
\text { Aldrich }\end{array}$ \\
\hline $\begin{array}{l}\text { 2- } \\
\text { Quinolinecarboxylic } \\
\text { acid }\end{array}$ & 18 & & 884.2 & 0.266 & 1.28 & $\begin{array}{l}\text { Sigma- } \\
\text { Aldrich }\end{array}$ \\
\hline 3-Nitro-4-quinolinol & 19 & & 1324 & 0.315 & 1.07 & $\begin{array}{l}\text { Sigma- } \\
\text { Aldrich }\end{array}$ \\
\hline Quinoline & 20 & & $\begin{array}{c}\text { Not } \\
\text { converged }\end{array}$ & & & $\begin{array}{l}\text { Sigma- } \\
\text { Aldrich }\end{array}$ \\
\hline
\end{tabular}

Table S2. Structures, $I C_{50}$ values, and dose-response curve fitting parameters for nitroxoline and all nitroxoline analogs tested for activity against $B$. mandrillaris. $\mathrm{IC}_{50}, \mathrm{R}^{2}$, and Hill slope values were calculated based on sigmoidal curves fit to 8-point dose-response experiments performed in triplicate. Compounds 2, 4-12, and 14 were the most potent inhibitors of $B$. mandrillaris, most likely due to the presence of an 8-position hydroxyl group or bidentate ligand on the quinoline ring, which are predicted to be necessary for metal binding activity. 